\title{
Processes controlling a volcaniclastic turbiditic system during the last climatic cycle: Example of the Cilaos deep-sea fan, offshore La Réunion Island
}

\author{
Emmanuelle Sisavath $^{\mathrm{a}, \mathrm{b}, *}$, Aude Mazuel ${ }^{\mathrm{c}}$, Stephan J. Jorry ${ }^{\mathrm{b}}$, Nathalie Babonneau ${ }^{\mathrm{c}}$, Patrick Bachèlery ${ }^{\mathrm{d}}$, \\ Béatrice de Voogd ${ }^{e}$, Marie Salpin ${ }^{f}$, Laurent Emmanuel ${ }^{f}$, Luc Beaufort ${ }^{g}$, Samuel Toucanne ${ }^{b}$
}

\footnotetext{
a Laboratoire GéoSciences Réunion, Université de la Réunion, Institut de Physique du Globe de Paris, Sorbonne Paris-Cité, CNRS, UMR7154, 15 avenue René Cassin, BP 7151. 97715 Saint Denis messag Cedex 9, La Réunion, France

b IFREMER, Géosciences Marines, Laboratoire Environnements Sédimentaires, BP70, 29280 Plouzané, France

c UMR6538 Domaines Océaniques, IUEM, Université de Brest, Place Copernic, 29200 Plouzané, France

d Laboratoire Magmas et Volcans UMR 6524, CNRS-IRD-Université Blaise Pascal, Observatoire de Physique du Globe de Clermont-Ferrand, 5 rue Kessler 63038 Clermont-Ferrand, France

e Université de Pau et des pays de l'Adour et CNRS FR 2952, 64000 Pau, France

f Université Pierre et Marie CURIE, laboratoire Biominéralisation et Environnements Sédimentaires, ISTeP-CNRS, UMR7193, 75252 Paris Cedex 05, France

${ }^{g}$ CNRS, Aix-Marseille Univ, CEREGE, UMR6635, 13545 Aix en Provence cedex 4, France
}

\author{
*: Corresponding author: Emmanuelle Sisavath, Tel.: + 33229008565 ; fax: + 33298224570 ; \\ email address : sisavath emmanuelle@hotmail.fr
}

\begin{abstract}
:
The present study focused on turbidite sedimentation in the Cilaos turbidite system, a volcaniclastic deep-sea fan recently recognized offshore La Réunion Island. A set of piston cores was collected in order to establish the stratigraphy of this fan and to examine the processes controlling the turbidite sedimentation off the Cilaos cirque (Piton des Neiges volcanic massif) over the last climatic cycle. Two main phases of turbidite activity were identified, during the ca $140-127 \mathrm{ka}$ and $30-0$ ka periods, coinciding with the two last glacial-interglacial transitions (i.e., Terminations II and I). In addition to changes in climate and eustatic sea-level, these periods coincide with a low effusive volcanic activity of the Piton des Neiges volcano. The high erosional rates identified in the Cilaos cirque during these intervals of both low effusive volcanic activity and enhanced rainfall level are probably the main driver of sediment supply to the deep-sea depositional system. These new findings also highlight the important capacity of volcaniclastic turbidite systems to record rapid paleoenvironmental changes.
\end{abstract}

Keywords : Turbidites ; La Réunion Island ; Indian Ocean ; Late Quaternary ; Volcaniclastic system

\section{Introduction}

Recent studies based on high-resolution stratigraphy show that past climate and sea-level changes have had a significant influence on deep ocean turbidite sedimentation at both orbital and millennial timescales. These relationship has been demonstrated over the last few years along both siliciclastic ( [Covault et al., 2007], [Jorry et al., 2008], [Toucanne et al., 2008], [Ducassou et al., 2010], [Jorry et al., 2011] and [Toucanne et al., 2012] among others) and carbonate margins (e.g., [Droxler and Schlager, 1985], [Schlager et al., 1994], [Andresen et al., 2003] and [Jorry et al., 2010]). Surprisingly, few studies have yet addressed the timing of gravity deposits around volcanic islands, and the forcing factors controlling the sediment delivery in such situations remain unclear ( [Alibés et al., 1999] and [Frenz et al., 2009]). 
The conventional sequence stratigraphy model for clastic systems states that deep marine systems preferably grow during falls in sea-level and at lowstand. However, several studies have demonstrated that some turbidite systems do not follow the classic sequence stratigraphy concepts. Covault and Graham (2010) showed that deep-sea deposition occurs at all sea-level states. Terrigenous sediment delivery to the deep-sea depends on many factors, such as the tectono-morphologic character of the margin, climatic forcing and terrestrial sediment source. The influence of climate and sea-level changes on sediment delivery to volcaniclastic basins is poorly defined and remains a matter of debate. Quidelleur et al. (2008) and McMurtry et al. (2004) suggested that most large volume landslides affecting volcanic islands occur at glacialinterglacial transitions (Terminations) and concluded there was a causal relationship between flank collapses of volcanic islands and global climate change. However, recent data contradict these results, as these showed no link between climate-driven changes and volcanic flank collapses (Harris et al., 2011; Longpré et al., 2011; Rodriguez-Gonzales et al., 2009). In contrast, the influence of volcanic activity has been widely examined, especially off the Canary Islands. In this area, the main turbidite activity has coincided with phases of high volcanic activity (Schmincke and Sumita, 1998; Schneider et al., 1998).

Since 2006, several oceanographic cruises have been conducted on the submarine flanks of La Réunion Island (Indian Ocean). These cruises led to the discovery of five volcaniclastic deepsea fans linked to major erosional structures visible on land (Saint-Ange et al., 2011; Sisavath et al., 2011). La Réunion Island offers the opportunity to study a deep depositional system related to an isolated oceanic island, situated far from continental influences. The aim of this paper is to establish the first stratigraphy of the Cilaos turbidite system based on a set of Küllenberg piston cores. We discuss how volcanic activity, climate and sea-level variations have interacted and controlled the input of sediment offshore of La Réunion island over the 
last $140 \mathrm{ka}$, leading to the building of a deep-sea fan spreading over hundreds of kilometers on the sea floor.

\section{Physical setting}

\subsection{General setting of La Réunion Island}

La Réunion Island is an isolated volcanic system located $750 \mathrm{~km}$ from Madagascar in the western part of the Indian Ocean (Fig. 1). It belongs to the Mascarene Archipelago and resulted from the activity of the hotspot that formed the Deccan Trapps (65 Ma ago) and subsequently the Mascarene Plateau and Mauritius Island (Bonneville et al., 1988; Duncan et al., 1989; Morgan, 1981). It is the youngest and largest island in this group and the only one that has active volcanism today. The island is located on an isolated compartment of the oceanic crust ( $\sim 67 \mathrm{Ma})$ bordered by two fracture zones (FZ) separated by $350 \mathrm{~km}$ : the Mahanoro FZ to the west and Mauritius FZ to the east (Fig. 1).

La Réunion Island s.s. is the emerged part of a volcanic edifice rising from approximately $4200 \mathrm{~m}$ (the oceanic floor) to more than $3000 \mathrm{~m}$ above sea level. The subaerial island represents only three percent of the whole edifice (De Voogd et al., 1999). The submarine flanks of La Réunion Island are mostly built by accumulation of debris avalanche deposits (Lénat and Labazuy, 1990; Oehler et al., 2004). In the southwestern part of the island, no major failures or flank collapses have produced deposits for $1 \mathrm{Ma}$ (Oehler et al., 2008).

The island is elliptical in shape $(50 \times 70 \mathrm{~km})$ and composed of two basaltic shield-volcanoes: Piton des Neiges and Piton de la Fournaise (Fig. 1). Activity of Piton de la Fournaise (2632 $\mathrm{m}$ high) started less than 0.6 Ma ago and this volcano is still highly active (Gillot and Nativel, 1989). Its morphology is marked by a succession of calderas open to the sea on their eastern 
101 sides (Fig. 1). The historic volcanic activity of Piton de la Fournaise has been described by

102 Bachelery et al. (1983), Lenat et al. (2009), Michon and Saint-Ange (2008), Peltier et al. $103(2009 ; 2008)$ and Stieltjes et al. (1988).

104 The Piton des Neiges volcano (3070 m high) occupies the northwestern two thirds of the 105 island. The principal and most original feature of this volcano is the existence of three major 106 erosional depressions, called "cirques", opened in the heart of the volcano (Fig. 1). The 107 cirques were partly filled by unconsolidated detrital rocks such as volcanic debris, avalanche 108 deposits, debris flow deposits and other breccia (Arnaud, 2005; Bret et al., 2003; Fèvre, 2005;

109 Oehler et al., 2005). Piton des Neiges started to grow more than 2.17 Ma ago, and has been 110 inactive for at least 0.012 Ma (Deniel et al., 1992; McDougall, 1971; Quidelleur et al., 2010; 111 Smietana et al., 2010). Its subaerial shield-building stage, known as the Oceanite Series, 112 extended from 2 Ma to approximately $430 \mathrm{ka}$ (Deniel et al., 1992; McDougall, 1971; Upton 113 and Wadsworth, 1965). The second stage, known as the Differentiated Series, occurred 114 between 350 and 12 ka (Deniel et al., 1992; Gillot and Nativel, 1982; McDougall, 1971), with 115 the end of the main effusive activity at about $30 \mathrm{ka}$ (Gillot and Nativel, 1982). The second 116 stage can be divided into three sub-stages. The first, between 350 and $180 \mathrm{ka}$, corresponded to 117 the beginning of Piton des Neiges magmatic differentiation. This effusive activity produced 118 lava flows that covered most of the edifice, filling existing valleys (Gillot and Nativel, 1982).

119 The second sub-stage corresponded to a low effusive activity period lasting 40 ka (Kluska, 120 1997), with mainly explosive activity (Kieffer, 1990). Kluska (1997) suggested that this was a 121 major erosional period corresponding to the formation of large and deep depressions: the 122 cirques. A second period of effusive activity took place between 140 and $30 \mathrm{ka}$. 
126 La Réunion Island is located in the subtropical zone, where it is influenced by the South

127 Equatorial Current and subjected to a prevailing southeasterly trade-wind regime. Trade 128 winds from the east induce highly variable precipitation regimes in time and space, which

129 lead to the island having a wet windward side (East) and a dry leeward side (West). Rainfall 130 also varies according to the elevation (dry coast - wetter upland), with maximum rain in the 131 mid-slope area. Average annual rainfall varies from over $12000 \mathrm{~mm}$ per year between 1300 132 and $2000 \mathrm{~m}$ altitude on windward slopes, to as low as $600 \mathrm{~mm}$ near the leeward coast.

133 The late Quaternary climate of La Réunion Island is largely unknown, as no data are available 134 for this area.

\subsection{Drainage basins and rivers}

On La Réunion Island, the wet tropical climate and basaltic terrains cause high erosion rates, which are amplified by seasonal cyclonic conditions (Louvat and Allegre, 1997; Rad et al., 2007). These erosion rates are close to those estimated in active orogenic areas, with values

141 ranging between $0.47-3.4 \mathrm{~m} \cdot \mathrm{kyr}^{-1}$. They result in a dense hydrographic network with more

142 than 750 gullies and rivers on the island, concentrated in drainage basins like the cirques and 143 the main valleys. These drainage basins are located between the planeze areas (Ollier and

144 Terry, 1999), which are relatively unaffected by erosion because water penetrates rather than 145 forming surface runoff (Fèvre, 2005). In the drainage basins, the rivers are torrential with 146 mechanical erosion rates among the highest measured in the world, ranging from 1200 to $1479100 \mathrm{t} / \mathrm{km}^{2} / \mathrm{yr}$ (Louvat and Allegre, 1997).

148 One of the major rivers of the island is the "Rivière Saint-Etienne". It is a torrential river

149 formed by the junction of the "Bras de Cilaos", which drains the inner part of the Cirque of 150 Cilaos, and the "Bras de la Plaine", which drains the outer eastern part (Fig. 1). The Saint- 
151 Etienne River has a drainage basin of about $200 \mathrm{~km}^{2}$ reaching altitudes of 2500 to $3000 \mathrm{~m}$. Its

152 mean fluvial solid load is estimated around $470000 \mathrm{~m}^{3} / \mathrm{yr}$; up to $1-2$ million $\mathrm{m}^{3} / \mathrm{yr}$ during

153 large floods (SOGREAH, 1998). In addition to this drainage basin, the outer western part of

154 the Cirque of Cilaos is incised by many gullies (Fig. 1). The resulting drainage basin for the

155 Cirque of Cilaos ("Rivière Saint-Etienne" and gullies) is about $360 \mathrm{~km}^{2}$.

156 The transition between the subaerial and submarine environments is marked by a narrow

157 shelf. The local absence of this shelf and the presence of steep submarine slopes around the

158 island imply a rapid transfer of sediment from the coast toward the base of the volcanic

159 edifice, allowing the formation of a volcaniclastic deep sea fan.

160

161

\subsection{The Cilaos turbidite system}

162

163 Recent oceanographic cruises over the submarine flanks of La Réunion Island and the

164 surrounding oceanic plate led to the discovery of five volcaniclastic turbidite systems (Fig. 1)

165 extending over $200 \mathrm{~km}$ away from the island (Saint-Ange et al., 2011; Sisavath et al., 2011).

166 On land, these systems are related to major erosional features that constitute the main

167 drainage area of the island. In each case, submarine canyons are directly connected to the 168 main river mouths. The Mafate fan is connected to the Cirque of Mafate, and the Saint-Joseph

169 fan is the only system connected to the Piton de la Fournaise volcano. The latter is considered 170 an embryonic stage fan. Finally, the Cilaos fan is the widest fan and is connected to the 171 Cirque of Cilaos.

172 The Cilaos turbidite system is located to the southwest of La Réunion Island. It is more than

$173250 \mathrm{~km}$ long and covers an area of about $15000 \mathrm{~km}^{2}$. This sedimentary system extends from

174 the Saint-Etienne river mouth to the Mahanoro fracture zone (Fig. 1). It starts at the coast, 175 with a $70 \mathrm{~km}$ long bypass area that directly feeds a deep-sea fan developing at about $4500 \mathrm{~m}$ 
176 water depth. The Cilaos fan extends over a complex abyssal plain composed of NE-SW

177 volcanic ridges (Saint-Ange et al., 2011).

178 The canyon area (Fig. 1; outlined in blue) is composed of two main canyons, Saint-Etienne

179 and Pierrefonds. The Pierrefonds canyon is located in front of the older Saint-Etienne River

180 delta and is connected to the shelf by many tributary canyons. The Saint-Etienne canyon is 4

$181 \mathrm{~km}$ wide and is directly connected to the present day Saint-Etienne River. Both canyons

182 merge into the single wide Cilaos canyon, which feeds the main deep sea fan body.

183 The fan can be divided into two parts: the proximal fan (Fig. 1; outlined in red) and distal fan

184 (Fig. 1; outlined in yellow). The proximal fan is broad, with a maximum width of $120 \mathrm{~km}$ and

185 low reflectivity of backscatter data. It is composed of elongated bodies, interpreted as small

186 lobes. The sedimentation in the proximal fan is characterized by coarse sandy turbidites

187 (Sisavath et al., 2011). The distal fan is divided into three parts, western, central and eastern,

188 by pre-existing volcanic ridges. The distal prolongation of the turbidite system is visible at the

189 ends of the western and central parts. It is characterized by elongated structures, extending via

190 narrow channels from the proximal fan. The sediments of the distal fan are composed of a

191 succession of fine sandy turbidites covered by a thick clay layer (about $3 \mathrm{~m}$ in thickness; Figs.

1922 and 3).

193

194 3. Materials and Methods

195

196 In this paper, we used seven Küllenberg piston cores taken around La Réunion Island during

197 the oceanographic cruises ERODER 1, onboard the BHO Beautemps-Beaupré in 2006;

198 FOREVER, onboard the R/V Atalante in 2006; and ERODER2, onboard the R/V Meteor in

199 January 2008 (Fig. 1, Table 1). Five cores were taken from locations in the Cilaos fan

200 (KERO-09, KERO-16, KERO-12, KERO-15 and FOR-C1). Additional cores from the Mafate 
fan (KERO-07, Fig. 1) and the Saint-Joseph fan (KERO-08, Fig. 1) were used to build a

202 regional age model. All the cores were situated and correlated using Parasound and $3.5 \mathrm{kHz}$ 203 echosounder profiles acquired during the FOREVER and ERODER2 cruises (Fig. 3). 204 Sedimentary descriptions were made of all the cores, with a particular emphasis on sediment 205 color, visual grain size and turbidite/hemipelagite/pelagite differentiation. Two main types of 206 sediment were distinguished: volcaniclastic sandy turbidites and hemipelagic sediments.

207 A series of 1-cm-thick sediment slabs were collected from each split core section and examined by X-radiography using a SCOPIX digital X-ray imaging system (Migeon et al., 1999). Digital images were acquired to provide a precise identification of the sedimentary 210 structures. Sediment cores were sampled for grain-size analyses using a Coulter laser micro211 granulometer (LS130). The variation of Ca through each of the cores was measured with an 212 Avaatech XRF Core-Scanner equipped with a variable optical system allowing measurements at resolutions between 10 and $0.1 \mathrm{~mm}$. The selected measurement area was $8 \mathrm{~mm}$ and the 214 step-size was set at $1 \mathrm{~cm}$.

215 Oxygen isotope analyses were conducted on small batches of Globigerinoides rubber, the 216 monospecific planktonic foraminifer that calcifies in the surface mixed layer, from cores 217 KERO-07, KERO-08, KERO-09 and KERO-16. Samples were collected at hemipelagic 218 intervals, representing intervals of continuous sedimentation, excluding turbidites. Cores were 219 sub-sampled with a sample spacing of 5 to $20 \mathrm{~cm}$. On average, 15 specimens were picked out 220 from the $>150 \mathrm{~mm}$ fraction. Using a common $100 \%$ phosphoric acid bath at $90^{\circ} \mathrm{C}, 20-50 \mu \mathrm{g}$ 221 of sample were reacted and analyzed using a GV Isoprime isotope ratio mass spectrometer at 222 University of Pierre \& Marie Curie (Paris). Isotope values are given in delta notation relative to Vienna Peedee belemnite. Repeated analyses of a marble working standard (calibrated against the international standard NBS-19) indicate an accuracy and precision of $0.1 \%$ o $(1 \sigma)$. 
225 In core KERO-16, the last occurrence of pink-pigmented G. ruber indicates the transition 226 between Marine Isotopic Stage (MIS) 6 and MIS 5 (Thompson et al., 1979).

227 Nine AMS radiocarbon dates were obtained on the cores (Table 2). For each sample, about 10 $228 \mathrm{mg}$ of G. ruber and G. sacculifer specimens were picked out from the $>150 \mathrm{~mm}$ fraction, 229 washed in an ultrasonic bath with distilled water, and dried. These samples were then 230 analyzed at the Poznan Radiocarbon Lab., Poland, and at the "Laboratoire de Mesure du 231 Carbone 14" at Saclay, France. Reported radiocarbon ages were corrected for a marine 232 reservoir effect of 400 years and converted to calendar years using CALIB Rev 6.0 (Reimer et 233 al., 2009). Calibrated kilo years before the present will be referred as ka.

234 The preservation of the test surface of the foraminifer G. ruber was examined by Scanning 235 Electron Microscopy (SEM, Philips XL30). The analysis was performed on G. ruber from 236 seven samples studied for $\delta^{18} \mathrm{O}$ measurements (three in core KERO-09 and four in core 237 KERO-16). Foraminifera were placed on adhesive carbon tabs and coated with gold. The 238 observation of the test surfaces was done in the secondary electron mode at $10 \mathrm{kV}$ voltage and 239 at a distance of $10 \mathrm{~mm}$.

240 In core KERO-09, five representative samples associated with particular sedimentary facies 241 were also analyzed for calcareous nannofossil biostratigraphy (Table 3). Smear slides were 242 made directly from unprocessed samples and were examined with a polarized light 243 microscope at a magnification of $1000 \times$.

\section{$245 \quad 4 . \quad$ Results}

\subsection{Lithology and echosounding facies}


Based on the grain-size characteristics, internal sedimentary structures, erosive contacts with underlying sediments and the abundance of glass shards and volcanic crystals, all the sandy beds in the studied cores were interpreted as volcaniclastic turbidites (Saint-Ange et al., 2011; Sisavath et al., 2011). These turbidite units ranged from a few centimeters up to $20 \mathrm{~cm}$ in thickness (Fig. 2).

Cores KERO-09 and KERO-12, taken in the western part of the Cilaos distal fan at about $215 \mathrm{~km}$ from the island, were 6.27 and $6.40 \mathrm{~m}$ long, respectively (Fig. 1). The lower parts of these cores are characterized by a succession of four sandy units of 30 to $50 \mathrm{~cm}$ thick, composed of well-sorted fine sand showing typical Bouma Tb to Te sequences (Bouma, 1962) (Fig. 3). On the echosounder profiles, this lowest unit corresponds to a stratified unit named U1 (Fig. 3). A thick layer of clay (about $3 \mathrm{~m}$ thick), showing an alternation of light 260 brown clay and darker brown clay, overlies this unit. The light brown clay is dominated by calcareous sediment (composed of nannoplankton and foraminifera), while the dark brown clay mainly contains siliceous organisms (radiolarians and diatoms). On the echosounder profiles, it corresponds to a semi-transparent unit, named U2 (Fig. 3).

Core KERO-15 was taken in the most distal part of the Cilaos distal fan at about 280 $265 \mathrm{~km}$ from the island (Fig. 1). This $6.68 \mathrm{~m}$-long core shows a sedimentary pattern similar to that 266 observed in cores KERO-09 and KERO-12. The base of the core shows a succession of seven 267 fine-sandy layers (20 to $80 \mathrm{~cm}$ thick) with typical Bouma $\mathrm{Tb}$ to Te sequences, and belongs to 268 unit U1 on the echosounder profiles (Fig. 3). The upper part of the core is composed of a clay 269 layer of about $2 \mathrm{~m}$ thick showing an alternation of light brown clay and darker brown clay, 270 corresponding to the unit U2 on the echosounder profiles (Fig. 3).

272 the Cilaos distal fan, on the right side of a channel. Clay layers (alternation of light brown 273 clay and darker brown clay) dominate the lithological succession in the lower part of the core, 
274 which locally includes small bioturbation features. This unit corresponds to unit U2 on the 275 echosounder profiles. At the top of the core (0-1.4 meters below seafloor, mbsf), fine-grained 276 turbidite deposits of few centimeters thickness are visible (Fig. 2). They were interpreted as 277 overflow deposits. On the echosounder profiles, they correspond to the upper part of the 278 profiles, characterized by a stratified unit named U3.

Core FOR-C1 was taken at the top of a sedimentary ridge in the central part of the 280 distal fan at a water depth of $4074 \mathrm{~m}$ (Fig. 1). The 2.50 meters forming the base of the core 281 are composed of an alternation of clay and thin sandy turbidites (less than $10 \mathrm{~cm}$ thick). This 282 unit corresponds to the unit U1 on the echosounder profiles (Fig. 3). It is overlain by $1.50 \mathrm{~m}$ 283 of clay (alternation of light brown clay and darker brown clay) corresponding to the semi284 transparent unit U2 on the echosounder profiles (Fig. 3). The top $0.54 \mathrm{~cm}$ are composed of 285 clay interbedded with thin sandy layers (1 cm thick), interpreted as overflow deposits and corresponding to the stratified unit U3 on the echosounder profiles (Fig. 3). long core from the left side of the canyon area (Fig. 1). The lower two thirds of the core correspond to a succession of sandy and silty turbidite sequences that are variable in 290 thickness, while the upper third is composed of silty-clay (Fig. 2). Core KERO-08 was taken near the volcanic ridge R4 at a water depth of $4126 \mathrm{~m}$, in

292 the distal part of the Saint-Joseph fan. Its lithological succession is composed of a succession 293 of sandy and silty turbidites whose thicknesses range from 2 to $15 \mathrm{~cm}$. These well-sorted 294 turbidites show normal grading and horizontal laminations. In the dark sandy layers, 295 laminations are underlined by white laminae characterized by abundant foraminifera and 296 bioclasts. Some clay and silty clay layers are highly bioturbated. 
300 The chronostratigraphic framework of cores KERO-09, KERO-16, KERO-07 and KERO-08

301 was established through integration of radiocarbon dating, planktonic oxygen isotope, 302 biostratigraphic markers and XRF records.

303 The $\delta^{18} \mathrm{O}$ curves show similar trends between all cores (Figs 5 and 6 ). The upper parts of the 304 cores show light $\delta^{18} \mathrm{O}$ values (down to $-2.0 \%$ in core KERO-07). A rapid increase of the $\delta^{18} \mathrm{O}$ 305 signal is observed thereafter, and heavier $\delta^{18} \mathrm{O}$ values (from -1.0 to $0 \%$ ) characterized the 306 lower parts of the cores (Fig. 4). Peaks and troughs recognized in the oxygen isotope records 307 were correlated with the reference isotopic signal published by Fretzdorff et al. (2000) from 308 La Réunion area, in agreement with the trends of the $\delta^{18} \mathrm{O}$ benthic stack record of Lisieky and 309 Raymo (2005) (Figs. 4 and 5).

310 The light $\delta^{18} \mathrm{O}$ values observed in the upper part of the cores correspond to the Holocene $(<11$

$311 \mathrm{ka})$. MIS2 is characterized by values of $\delta^{18} \mathrm{O}$ between 0 and $-0.5 \%$. A general decrease of the $312 \delta^{18} \mathrm{O}$ values from 0 to $-1 \%$ is clearly shown in MIS3 (Fig. 5). It is followed by an increase of $313 \delta^{18} \mathrm{O}$ values identified as the MIS3/MIS4 transition. The relatively light $\delta^{18} \mathrm{O}$ values $(>-1 \%$ ) 314 observed in the lower part of cores from the Cilaos fan correspond to the last interglacial. The 315 oxygen isotope stratigraphy of all these cores provides a regional record of the last climatic 316 cycle around La Réunion Island.

317 In cores of the Cilaos fan (KERO-09 and KERO-16), MIS-5 is characterized by $\delta^{18} \mathrm{O}$ values 318 ranging between $-1 \%$ and $0 \%$, which are unusually low for the last interglacial compared 319 with those published by Fretzdorff et al. (2000) (Fig. 5). SEM observations of the test surface 320 of $G$. ruber in cores KERO-09 and KERO-16 reveal some dissolution pockets and 321 recrystallized areas (Fig. 6), which could explain these inconsistent $\delta^{18} \mathrm{O}$ values. In addition, periods of high carbonate dissolution have been identified in the western part of the Indian 
ocean, mainly during interglacials (Divakar et al., 1993). However, this chronostratigraphy was supported by the study of biostratigraphic markers. The nannofossil assemblage in core KERO-09 contains abundant E. huxleyi at $65 \mathrm{~cm}$ below seafloor (bsf), suggesting an age younger than 75-90 ka (Berggren et al., 1995). Samples from 115-117 and $361 \mathrm{~cm}$ bsf show abundant well preserved nannofossils. The occurrence of $E$. huxleyi and the absence of $P$. lacunosa suggest that these samples are younger than 260 ka (Berggren et al., 1995). The sample from $608 \mathrm{~cm}$ bsf has abundant but a poorly preserved nannofossils. Gephyrocapsa spp cf caribbeanica is dominant and two $P$. lacunosa are present, suggesting an age younger than 460 ka (Berggren et al., 1995). The last occurrence of pink pigmented G. ruber is also observed in core KERO-16 at $4.70 \mathrm{~m}$ bsf, suggesting that the upper $4.70 \mathrm{~m}$ of KERO-16 is aged 120 ka (Thompson et al., 1979).

All these data provide a consistent age model around La Réunion Island. This age model was extended to other cores of the Cilaos fan (KERO-12, KERO-15 and FOR-C1) using the XRF records. The age model of cores FOR-C1, KERO-12 and KERO-15 was established by correlating the Ca variation of cores KERO-09 and KERO-16 (Fig. 7). In all the cores, light brown clays, corresponding to high XRF Ca values, allow a reliable core-to-core correlation.

\subsection{Lithostratigraphy}

The lithostratigraphy in the Cilaos fan was established with cores KERO-09, KERO-12, KERO-15, KERO-16 and FOR-C1. Based on the age model, the five cores retrieved from the Cilaos fan extend from $10 \mathrm{ka}$ to $130 \mathrm{ka}$, with the Holocene period only being recorded for KERO-16 (Fig. 4). Although distances of tens of kilometers separate them, the variation of the calcium XRF correlates well between the five cores through the last glacial-interglacial cycle (Fig. 7). The cores exhibit a common sediment pattern and a fairly similar 
sedimentation rate. They are all composed of a succession of turbidites covered by a thick

349 clay layer (Fig. 2). The sedimentation rate in the hemipelagic layer ranges between 1.8 and

$3505.2 \mathrm{~cm} / \mathrm{ka}$ (Fig. 8). These results are comparable to the minimum sedimentation rate of 1.9

$351 \mathrm{~cm} / \mathrm{ka}$ observed by Ollier et al. (1998), based on micropaleontological analysis. They also

352 correlate with the sedimentation rates measured by Fretzdorff et al. (2000) in core S 17-666,

353 near the Mafate fan (Fig. 1), based on a $\delta^{18} \mathrm{O}$ stratigraphy (Fig. 4). In this core (S17-666),

354 three stages can be observed in the sedimentation: 1) between 128 and $186 \mathrm{ka}$, with a

355 sedimentation rate of $4.14 \mathrm{~cm} / \mathrm{ka} ; 2)$ between 26 and $128 \mathrm{ka}$, with an average rate of

356 sedimentation of $2.27 \mathrm{~cm} / \mathrm{ka}$; and 3) between 14.5 and $26 \mathrm{ka}$, with a sedimentation rate of

$3574.35 \mathrm{~cm} / \mathrm{ka}$. If we calculate the mean of the sedimentation rates in our cores for each period,

358 we obtain sedimentation rates of about $4.9 \mathrm{~cm} / \mathrm{ka}$ for the first stage, $2.73 \mathrm{~cm} / \mathrm{ka}$ for the second

359 stage and $3.02 \mathrm{~cm} / \mathrm{ka}$ for the third. The sedimentation rates lie between those of the Mafate

360 and Cilaos systems, with two stages of relatively high sedimentation rate interrupted by a

361 period of low sedimentation.

362 These three distinct phases of sedimentation correlate with the three sedimentary units

363 identified in the cores of the Cilaos turbidite system. The first unit corresponds to the turbidite

364 activity visible in the lower part of cores KERO-09, KERO-12 KERO-15 and FOR-C1,

365 characterized by sandy turbidites of 30 to $50 \mathrm{~cm}$ thickness (Fig. 3 ) and corresponding to the

366 stratified unit U1 on the echosounder profiles (Fig. 3). This first stage is characterized by 367 turbidity currents that spread over the entire fan (Sisavath et al., 2011). This first documented 368 phase of turbidite activity would have deposited until the end of MIS5 (Fig. 8). Therefore, 369 according to the age model of figure 8, the top of unit U1 - marking the interruption of this 370 first phase of turbidite activity - corresponds to an age of 125-127 ka.

371 The second phase is characterized by a thick clay layer observed in all the cores (Fig. 2) and 372 by the absence of major turbidite activity. Only a few thin sandy layers are observed in cores 
373 FOR-C1 and KERO-16 (Fig. 8). On the echosounder profiles, this unit coincides with the

374 semi transparent unit U2, visible over the entire fan except in the more proximal part 375 (Sisavath et al., 2011). The timing of clay deposition ranged from MIS3 to MIS5 (Fig. 8). The 376 top of unit U2, visible in the upper part of cores KERO-16 and FOR-C1, lies within the lower 377 part of MIS2 at about $30 \mathrm{ka}$ (Fig. 8).

378 The third phase is characterized by thin sandy layers observed in cores FOR-C1 and KERO37916 (Fig. 3), with sediments coarser than in the older phase of turbidite activity. These turbidite 380 events were observed on the proximal fan and into the channels of the distal fan (Sisavath et 381 al., 2011). They are characterized, on the echosounder profiles, by a stratified unit (U3) 382 visible in the upper part of the profiles (Fig. 3). This phase corresponds to the most recent 383 activity of the Cilaos fan and was deposited during MIS1 and MIS2 until $30 \mathrm{ka}$.

\section{Discussion}

This discussion is based on cores KERO-09, KERO-12, KERO-15, KERO-16 and FOR-C1.

388 Cores KERO-07 and KERO-08 were used to build a consistent regional $\delta^{18} \mathrm{O}$ stratigraphy 389 around La Réunion Island.

391 5.1. Sedimentation in the Cilaos fan over the last $140 \mathrm{ka}$

393 Three distinct episodes of sedimentation correlate with three sedimentary units identified in 394 the cores of the Cilaos turbidite system. The first unit corresponds to the oldest turbidite 395 activity, visible in the lower part of cores KERO-09, KERO-12 KERO-15 and FOR-C1. This 396 first unit, spreading over the entire fan (Sisavath et al., 2011), is characterized by sandy turbidites of 30 to $50 \mathrm{~cm}$ thick (Fig. 3) and corresponds to the stratified unit U1 on the 
echosounder profiles (Fig. 3). According to our age model (Fig. 8), the first period of turbidite

399 activity began before $140 \mathrm{ka}$ and ended at $\sim 125-127 \mathrm{ka}$ (which coincides with the MIS5

400 highstand).

401 The second phase is characterized by a thick clay layer observed in all the cores (Fig. 2)

402 which illustrates the absence of major turbidite activity. Only a few thin sandy layers are

403 observed in cores FOR-C1 and KERO-16 (Fig. 8). On the echosounder profiles, this unit

404 coincides with the semi transparent unit U2, visible over the entire fan except in the more 405 proximal part (Sisavath et al., 2011). The timing of clay deposition ranged from MIS3 to

406 MIS5 (Fig. 8). The top of unit U2, visible in the upper part of cores KERO-16 and FOR-C1,

407 lies within the lower part of MIS2 at about $30 \mathrm{ka}$ (Fig. 8).

408 The third phase is marked by the deposition of thin sandy layers as observed in cores FOR-C1

409 and KERO-16 (Fig. 3), with sediments coarser than those deposited during the older U1 unit.

410 These turbidite events were active in the proximal fan and into the channels of the distal fan

411 (Sisavath et al., 2011). They are characterized, on the echosounder profiles, by a stratified unit

412 (U3) visible in the upper part of the profiles (Fig. 3). This phase corresponds to the most

413 recent activity of the Cilaos turbiditic fan since $30 \mathrm{ka}$ until Holocene.

414 A significant difference in sedimentation rate is observed between core KERO-16 (located 415 near the main channel of the central part of the Cilaos fan, showing the highest sedimentation 416 rate) and the other cores KERO-09, KERO-15, KERO-12 and FOR-C1 (Fig. 9). The location 417 of cores KERO-09, KERO-15 and KERO-12 at the termination of the distal fan might explain 418 a lower sediment supply compared to the upper/central part of the Cilaos fan. The location of 419 core FOR-C1 on top of a sedimentary ridge (about 200 m-high) explain sedimentation rates 420 significantly lower than those observed in KERO-16.

421 In the distal part of the Cilaos fan, sedimentation rate is rather homogeneous until $\sim 60 \mathrm{ka}$ and 422 decreases from $\sim 60 \mathrm{ka}$ to $\sim 10 \mathrm{ka}$ (Fig. 9), which corresponds to the progressive abandon of 
423 the turbiditic sedimentation in the western distal part of the Cilaos fan since $\sim 60$ ka (Sisavath 424 et al., 2011). The increase of sedimentation rate from $\sim 100$ ka to $\sim 45$ ka in cores KERO-16 425 and FOR-C1 reflects a turbiditic activity restricted to the central part of the fan.

426 From $\sim 45 \mathrm{ka}$ to $\sim 30 \mathrm{ka}$, decrease in sedimentation rates in all cores can be interpreted as a 427 major change in the sediment supply at the scale of the entire Cilaos deep-sea fan (Fig. 9). 428 This period coincides with the youngest phase of effusive volcanic activity of the Piton des 429 Neiges (Kluska, 1997, Salvany et al., 2012), which has probably contributed to fill the cirques 430 and the fluvial valleys. At $\sim 30 \mathrm{ka}$, the major increase in sedimentation rates detected in core 431 KERO-16 corresponds to a new episode of turbidite activity (unit U3, Fig.9) restricted to the 432 central part of the fan (Sisavath et al., 2011).

5.2. Unravelling the forcing factors of turbidite sedimentation in the Cilaos fan over the last $140 \mathrm{ka}$

The three main forcing factors controlling sediment supply and transport offshore volcanic 438 islands are volcanic activity, climate and sea-level (Krastel et al., 2001, Quidelleur et al., 439 2008). Recent works on the morphology and sedimentary architecture of the Cilaos fan show 440 that the sedimentary processes involved in the feeding of the Cilaos turbidite systems are 441 direct feeding by rivers and submarine slope instabilities (Saint-Ange et al., 2011; Sisavath et 442 al., 2011). The detailed stratigraphy of the Cilaos fan obtained in the present study allows us 443 to test this assumption over the last climatic cycle.

\subsubsection{Turbidites in relation to climate and sea-level fluctuations}

446 Offshore La Réunion Island, the two main intervals of turbidite activity coincide with the 447 transition from glacial lowstand to highstand condition. The first phase of turbidite deposits 
448 coincided with lowstand and rising sea-level, at about $137 \mathrm{ka}$ and between 137 and $130 \mathrm{ka}$, 449 respectively (Rohling et al., 2009; Fig. 8). The last recurrence of turbidite deposition in the 450 Cilaos system (unit U3) also coincided with such a sea-level pattern, the turbidite activity is 451 visible during the LGM lowstand (26 to $19.5 \mathrm{ka}$, Clark et al., 2009) and continuing until the 452 next highstand conditions. The intervening period did not show any turbiditic conditions.

453 A link between sea-level change and large scale landsliding is suggested by some authors (e. 454 g., McMurtry et al., 2004; Quidelleur et al., 2008). Sea-level variations can change the pore 455 pressure conditions, which are related to the location of the aquifer on top of a hydrothermal 456 unit (Join et al., 2005), or influence the submarine and coastal boundary conditions that 457 control groundwater flow in the volcanic edifice. In his study of factors that could induce 458 large flank destabilization on shield volcanoes, Iverson (1995) had already concluded to the 459 minor role played by sea level changes. When the sea-level drops, the mechanical resistance 460 of the hydrothermal unit decreases as the pressure exerted by the water table at the base of 461 edifice increases. The mechanical resistance decreases until the rupture threshold is reached, 462 inducing a rapid lateral sliding of the volcano flank. This link between sea-level change and 463 large scale landsliding is not observed for the Cilaos fan because no flank collapses have 464 destabilized the studied area for $1 \mathrm{Ma}$ (Oehler et al., 2008). Moreover, turbidite activity is 465 visible during lowstand and highstand conditions, suggesting that sea-level variation has little 466 influence on the development of turbidites in the Cilaos deep-sea fan.

468 The lack of palaeoclimatic records from La Réunion Island preclude the direct correlation of 469 the turbidite activity in the Cilaos Fan with climate changes. An alternative is to examine the 470 palaeoclimatic reconstructions from southern Africa. Intense debate persists about the 471 climatic mechanisms governing hydrologic changes in this area (e.g., Schefuß et al., 2012). 472 However, recent results suggest that mean summer insolation controls the atmospheric 
convection, with higher insolation leading to higher rainfall (Schefuß et al., 2012). By considering this orbital forcing over a geological timescale, this implies that glacialinterglacial transitions in the southern African tropics were characterized by significant changes in rainfall level, from wet to dry conditions. Such a pattern has been demonstrated for the last Termination, through the runoff of the Zambezi river (Schefuß et al., 2012), and corroborates previous rainfall reconstructions from South Africa and Madagascar over the last 150-200 ka (Partridge et al., 1997; Gasse and Van Campo, 2001).

Based on a geomorphological approach, Saint-Ange et al. (2011) showed that the Cilaos Fan is directly connected to the Saint-Etienne river mouth. This implies that river runoff is a major forcing factor on sediment delivery to the Cilaos Fan, and that a high rainfall period in the southern African tropics would increase sediment supply to the deep-sea fan. A sediment delivery process of this type to a deep-depositional system has been demonstrated from short, mountainous river systems (e.g., Makran margin, Southern California; Bourget et al., 2010; Covault et al., 2010). Based on the rainfall reconstructions of Partridge et al. (1997) (Fig. 8), one would expect the turbidite sedimentation in the Cilaos Fan to increase during southern hemisphere summer insolation maxima. However, no turbiditic activity was recorded in the Cilaos Fan at the time of glacial rainfall maxima (e.g., ca 90, 70 or 50 ka; Partridge et al., 1997). Moreover, the turbidite activity off the St Etienne river, centred on Termination II and I, began at a time of wet (MIS 2) to very wet conditions (MIS 6) in the southern African tropics and continued during both the climatic transition (i.e., Terminations) and the following dry conditions (i.e., MIS 5 and MIS 1) (Partridge et al., 1997; Gasse and Van Campo, 2001). To understand the impact of climate on the development of turbidite in the Cilaos fan, it would be necessary to obtain more accurate data about the climatic variations in La Réunion Island but, according to current knowledge, the results presented here call into question the impact of rainfall level alone on sediment delivery to the Cilaos basin. 
501 The two main periods of turbidite activity in the Cilaos system coincided with periods of low 502 effusive volcanic activity at La Réunion. Indeed, the first phase of turbidite activity (unit U1) 503 can be associated with the low effusive activity identified between 180 and $140 \mathrm{ka}$ at Piton 504 des Neiges (Kluska, 1997; Salvany et al., 2012). The second period of turbidite activity (Unit 505 U3) began at the end of the effusive activity of the Piton des Neiges volcano, dated at about 30 ka by Gillot and Nativel (1982). These periods correlate with the major erosional episodes interpreted by Kluska (1997) and Salvany et al. (2012) (Fig. 10). The decrease of volcanic 508 production coincided with the erosional formation of the cirques (Kluska, 1997; Salvany et 509 al., 2012). This strongly suggests that the low effusive activity contributed to increasing the sediment input to the submarine flank and the deep Cilaos basin surrounding La Réunion Island. Conversely, the interruption of turbidite activity (between $127 \mathrm{ka}$ and $30 \mathrm{ka}$ ) coincided with a resumption of the effusive and explosive activity of the Piton des Neiges volcano, with 513 large lava flows that filled the cirques and their drainage valleys (Fig. 10) (Kluska, 1997, 514 Salvany et al., 2012). In the cirque of Cilaos, the first lava flows related to this new volcanic event are estimated to have appeared at $130 \mathrm{ka}$ (Kluska, 1997). The filling of the drainage basin by lava flows probably obstructed the pathways for sediment transfers to the deep

517 marine environment.

518 In the Canary Islands, for comparison, a clear relationship is observed between the timing of 519 emplacement of volcanic-rich turbidites and the period of explosive volcanic activity (Alibés 520 et al., 1999; Frenz et al., 2009). During volcanically active stages, an increase of sediment 521 transport from the volcanic island is observed, with major flank collapses feeding turbidite 522 currents (Frenz et al., 2009; Schneider et al., 1998). Schneider et al. (1998) also observed 
523 increases of turbidite activity during a non-eruptive period on Gran Canaria, suggesting that

524 sediments were transported by low-density turbidity currents with some turbidites related to 525 the dynamics of the fluvial system. Funck and Schmincke (1998) showed that many of the 526 submarine canyons of the Canary Islands are the continuation of onshore canyons. Mitchell et 527 al. (2003) and Krastell et al. (2001) concluded that the dominant process feeding these 528 canyons was hyperpycnal flow.

529 For the Cilaos fan, the occurrence of turbidite activity during periods of low effusive volcanic 530 activity suggests that the fan was mainly fed by river sediment load. This means that the 531 turbidite activity occurred when erosional processes dominated, allowing a vast transport of 532 sediment over the submarine flanks of the volcano. These periods also correspond to phases 533 of explosive activity of Piton des Neiges, which could also have produced a large amount of 534 volcaniclastic material during eruption and a rapid transfer of sediments down to the adjacent 535 slope and basin, in a similar way to what was suggested for the Canary Islands (Schminke and 536 Sumita, 1998).

537 As a result, the volcanic activity appears to be a major controlling factor influencing turbidite 538 development of the Cilaos deep-sea fan.

\section{Conclusions}

542 New stratigraphical data on the deep-sea Cilaos sedimentary system allow us to define the 543 timing of turbidite activity, which appears to have occurred close to the last two climatic 544 terminations. A first turbidite activity period occurred around $127 \mathrm{ka}$ and a second one started 545 at $30 \mathrm{ka}$, which has continued until the present. The two main phases of turbidite activity 546 coincide with the last two transitions from glacial lowstands to subsequent sea level rises. 547 Nevertheless, our study demonstrates that sea level change played a minor role in the 
548 triggering of turbidites in the Cilaos fan. On the other hand, the synchronicity between intense

549 turbidite deposition in the Cilaos deep-sea fan and periods of low effusive volcanic activity of 550 the Piton des Neiges volcano is clearly seen. We suggest that high erosional rates, identified

551 in the cirques during periods of low effusive activity, would mainly have contributed to 552 increase the seaward sediment transport. Conversely, the onset of volcanic activity would 553 have prevented intense erosion in the cirques, with the decrease of gravity deposits in the 554 Cilaos deep-sea fan resulting from the consequent low sediment transfer by rivers. Compared 555 with other volcaniclastic systems, explosive events of the Piton des Neiges might have also 556 contributed to feeding the Cilaos deep-sea fan.

\section{Acknowledgements}

560 The authors thank the crew and scientific teams for the high-quality data recovery during the 5612006 ERODER1 cruise aboard the BHO Beautemps-Beaupré and the 2008 ERODER 2 cruise 562 aboard the RV Meteor. Seven radiocarbon dates presented in this paper were acquired with 563 the Artemis program (supported by the CNRS). We are also grateful to Nathalie Labourdette 564 (Université Pierre \& Marie Curie) who ran the oxygen isotope analyses and to Tomasz Goslar 565 who managed additional radiocarbon dating at the Poznan Radiocarbon Laboratory (Poland). 566 Financial support was provided by the "Conseil Régional de La Réunion”, by the Institut 567 Universitaire Européen de la Mer (Brest), and by IFREMER (Project "French Territories 568 Indian Ocean"). The authors thank Marie-France Loutre for the insolation data and the two 569 reviewers Dr. Francky Saint-Ange and Dr. Neil C. Mitchell whose comments and suggestions 570 contributed to improve the original manuscript.

\section{References}


575 Alibés, B., Rothwell, R.G., Canals, M., Weaver, P.P.E., Alonso, B., 1999. Determination of sediment volumes, accumulation rates and turbidite emplacement frequencies on the Madeira Abyssal Plain (NE Atlantic): a correlation between seismic and borehole data. Marine Geology 160, 225-250.

Andresen, N., Reijmer, J.J.G., Droxler, A.W., 2003. Timing and distribution of calciturbidites around a deeply submerged carbonate platform in a seismically active setting (Pedro Bank, Northern Nicaragua Rise, Caribbean Sea). International Journal of Earth Sciences 92, 573-592.

Arnaud, N., 2005. Les processus de demantelement des volcans, le cas d'un volcan bouclier en milieu oceanique : le Piton des Neiges (Ile de La Réunion), Université de La Réunion, France, 422 pp.

Bachelery, P., Chevallier, L., Gratier, J.P., 1983. Structural characteristics of historical eruptions of the Piton de la Fournaise (Reunion Island). Comptes Rendus De l'Academie Des Sciences Serie II 296 (17), 1345-1350.

Berger, A.L., 1978: Long-Term Variations of Daily Insolation and Quaternary Climatic Changes. Journal of the Atmospheric Sciences, 35, 2362-2367.

Berggren, W.A. et al., 1995. Late Neogene chronology: New perspectives in high-resolution stratigraphy. Geological Society of America Bulletin 107 (11), 1272-1287.

Bonneville, A., Barriot, J.P., Bayer, R., 1988. Evidence from geoid data of a hotspot origin for the southern Mascarene Plateau and Mascarene Islands (Indian Ocean). Journal of geophysical research 93 (B5), 4199-4212.

Bouma, A.H., 1962. Sedimentology of some flysh deposits: a graphic approach to facies interpretation. Elsevier, Amsterdam, 168 pp. 
Bourget, J., Zaragosi, S., Mulder, T., Schneider, J.-L., Garlan, T., Van Toer, A., Mas, V., Ellouz-Zimmermann, N., 2010. Hyperpycnal-fed turbidite lobe architecture and recent sedimentary processes: A case study from the Al Batha turbidite system, Oman margin. Sedimentary Geology 229, 144-159.

Bret, L., Fevre, Y., Join, J.L., Robineau, B., Bachelery, P., 2003. Deposits related to degradation processes on Piton des Neiges volcano (Reunion Island): overview and geological hazard. Journal of Volcanology and Geothermal Research 123 (1-2), 25-41.

Clark, P.U. et al., 2009. The last glacial maximum. Science 325, 710-714.

Covault, J.A., Normark, W.R., Romans, B.W., Graham, S.A.,2007. Highstand fans in the California borderland: The overlooked deep-water depositional systems. Geology 35, 783-786.

Covault, J.A., Graham, S.A., 2010. Submarine fans at all sea-level stands: Tectonomorphologic and climatic controls on terrigenous sediment delivery to the deep sea. Geology 38 (10), 939-942.

De Voogd, B. et al., 1999. Vertical movements and material transport during hotspot activity: seismic reflection profiling offshore La Reunion. Journal of Geophysical ResearchSolid Earth 104, 2855-2874.

Deniel, C., Kieffer, G., Lecointre, J., 1992. New Th-230-U-238 and C-14 age determinations from Piton des Neiges volcano, Reunion-A revised chronology for the Differentiated Series Journal of Volcanology and Geothermal Research 51 (3), 253-267.

Divakar Naidu, P., Malmgren, B.A., Bornmalm, L., 1993. Quaternary history of calcium carbonate fluctuations in the western equatorial Indian Ocean (Somali Basin). Palaeogeography, Palaeoclimatology, Palaeoecology 103, 21-30.

Droxler, A.W., Schlager, W., 1985. Glacial versus interglacial sedimentation rates and turbidite frequency in the Bahamas. Geology 13 (11), 799-802. 
623 Ducassou, E. et al., 2010. Evolution of the Nile deep-sea turbidite system during the Late Quaternary: influence of climate change on fan sedimentation. Sedimentology 56, 2061-2090.

626

Duncan, R.A., Backman, J., Peterson, L., 1989. Reunion hotspot activity through tertiary time: initial results from the Ocean Drilling Program, leg 115. Journal of Volcanology and Geothermal Research 4, 193-198.

Fèvre, Y., 2005. Mécanismes et vitesses d'érosion à l'échelle géologique sur une île volcanique jeune à relief élevé - La Réunion (Océan Indien). Université de la Réunion, France, 217 pp.

Frenz, M. et al., 2009. Provenance and pathways of late Quaternary turbidites in the deepwater Agadir Basin, northwest African margin. International Journal of Earth Sciences $98(4), 721-733$.

Fretzdorff, S., Paterne, M., Stoffers, P., Ivanova, E., 2000. Explosive activity of the Reunion Island volcanoes through the past 260,000 years as recorded in deep-sea sediments. Bulletin of Volcanology 62 (4-5), 266-277.

Funck, T., Schmincke, H.U., 1998. Growth and destruction of Gran Canaria deduced from seismic reflection and bathymetric data. Journal of Geophysical Research 103 (B7), $393-407$.

Gasse F, Van Campo E. 2001. Late Quaternary environmental changes from a pollen and diatom record in the southern tropics (Lake Tritrivakely, Madagascar). Palaeogeography, Palaeoclimatology, Palaeoecology 167: 287-308

Gillot, P.Y., Nativel, P., 1982. K-Ar chronology of the ultimate activity of Piton des Neiges volcano, Reunion Island, Indian Ocean. J. Volcano. Geotherm. Res. 13, 131-146. 
647 Gillot, P.Y., Nativel, P., 1989. Eruptive history of the Piton de la Fournaise volcano, Réunion

648

649

650

651

652

653

654

655

656

657

658

659

660

661

662

663

664

665

666

667

668

669

670

671 Island, Indian Ocean. Journal of Volcanology and Geothermal Research 36 (1-3), 5365.

Harris, P.D., Branney, M.J., Storey, M., 2011. Large eruption-triggered ocean-island landslide at Tenerife: Onshore record and long-term effects on hazardous pyroclastic dispersal. Geology 39, 951-954.

Iverson, R.M., 1995. Can magma-injection and groundwater forces cause massive landslides on Hawaiian volcanoes? Journal of Volcanology Geotherm. Res. 66, 295-308.

Join, J.-L., Folio, J.-L.,Robineau, B., 2005. Aquifers and groundwater within active shield volcanoes. Evolution of conceptual models in the Piton de la Fournaise volcano. Journal of Volacnology and Geothermal Research 147, 187-201.

Jorry, S.J., Droxler, A.W., Francis, J.M., 2010. Deepwater carbonate deposition in response to re-flooding of carbonate bank and atoll-tops at glacial terminations. Quaternary Science Reviews 29, 2010-2026.

Jorry, S.J. et al., 2008. Bundled turbidite deposition in the central Pandora Trough (Gulf of Papua) since Last Glacial Maximum: Linking sediment nature and accumulation to sea level fluctuations at millennial timescale. Journal of geophysical research 113 (F01S19).

Jorry, S.J., Jégou, I., Emmanuel, L., Silva Jacinto, R., Savoye, B., 2011. Turbiditic levee deposition in response to climate changes: The Var Sedimentary Ridge (Ligurian Sea). Marine Geology 279 (1-4), 148-161.

Kieffer, G., 1990. Grand traits morphologiques de l'île de la Réunion (Océan Indien). In: J.F. Lénat (Ed.), Le Volcanisme de la Réunion - Monographie, pp. 75-114.

Kluska, J.M., 1997. Evolution magmatique et morpho-structurale du Piton des Neiges au cours des derniers 500000 ans, Paris XI. 
672 Krastel, S., Schmincke, H.U., Jacobs, C.L., 2001. Formation of submarine canyons on the flanks of the Canary Islands. Geo-Marine Letters 20 (3), 160-167.

674 Lenat, J.F. et al., 2009. Age and nature of deposits on the submarine flanks of Piton de la Fournaise (Reunion Island). Journal of Volcanology and Geothermal Research 184 (12), 199-207.

Lenat, J.F. and Labazuy, P., 1990. Morphologies et structures sous-marines de La Réunion. In "Le volcanisme de la Réunion, monographie", J-F Lénat Ed., pp379, 43-74.

Lisiecki, L.E., Raymo, M.E., 2005. A Pliocene-Pleistocene stack of 57 globally distributed benthic $\delta 180$ records. Paleoceanography 20 (PA1003), 1-17.

Longpré, M.-A., Chadwick, J.P., Wijbrans, J., Iping, R., 2011. Age of the El Golfo debris 682 avalanche, El Hierro (Canary Islands): New constraints from laser and furnace 40Ar/39Ar dating. Journal of Volcanology and Geothermal Research 203, 76-80.

Louvat, P., Allegre, C.J., 1997. Present denudation rates on the island of Reunion determined 685 by river geochemistry: Basalt weathering and mass budget between chemical and mechanical erosions. Geochimica et Cosmochimica Acta 61 (17), 3645-3669.

McDougall, I., 1971. The geochronology and evolution of the young volcanic island of Réunion, Indian Ocean. Geochimica et Cosmochimica Acta 35 (3), 261-288.

McMurtry, G.M., Watts, P., Fryer, G.J., Smith, J.R., Imamura, F., 2004. Giant landslides, mega-tsunamis, and paleo-sea level in the Hawaiian Islands. Marine Geology 203 (3-

Michon, L., Saint-Ange, F., 2008. Morphology of Piton de la Fournaise basaltic shield volcano (La Reunion Island): Characterization and implication in the volcano evolution. Journal of Geophysical Research-Solid Earth 113, B03203. system for core analysis. Geo-Marine Letters 18, 251-255. 
697 Mitchell, N.C., Dade, W.B., Masson, D.G., 2003. Erosion of the submarine flanks of the 698 Canary Islands. Journal of Geophysical Research-Earth Surface 108, F1-6002.

699 Morgan, W.J., 1981. Hot spot tracks and the opening of the Atlantic and Indian Oceans. In: C. 700 Emiliani (Ed.), The Sea. Wiley Interscience, New York, pp. 443-487.

701 Oehler, J.-F., Lénat, J.-F., Labazuy, P., 2008. Growth and collapse of the Reunion Island 702 volcanoes. Bulletin of Volcanology 70, 717-742.

703 Oehler, J.F., de Vries, B.V., Labazuy, P., 2005. Landslides and spreading of oceanic hot-spot 704 and arc shield volcanoes on Low Strength Layers (LSLs): an analogue modeling approach. Journal of Volcanology and Geothermal Research 144 (1-4), 169-189.

706

Oehler, J.F., Labazuy, P., Lenat, J.F., 2004. Recurrence of major flank landslides during the 707 last 2-Ma-history of Reunion Island. Bulletin of Volcanology 66, 585-598.

708 Ollier, G., Cochonat, P., Lenat, J.F., Labazuy, P., 1998. Deep-sea volcaniclastic sedimentary 709 systems: an example from La Fournaise volcano, Reunion Island, Indian Ocean. Sedimentology 45 (2), 293-330.

711 Ollier, C.D., Terry, J.P., 1999. Volcanic geomorphology of northern Viti Levu, Fiji. Australian Journal of Earth Sciences 46, 515-522

713 Patridge, T.C., Demenocal, P.B., Lorentz, S.A., Paiker, M.J., Vogel, J.C., 1997. Orbital 714 forcing of climate over South Africa: A 200,000-year rainfall record from the Pretoria Saltpan. Quaterrnary Science Reviews 16, 1125-1133.

716 Peltier, A., Bachelery, P., Staudacher, T., 2009. Magma transport and storage at Piton de La Fournaise (La Reunion) between 1972 and 2007: A review of geophysical and geochemical data. Journal of Volcanology and Geothermal Research 184 (1-2), 93108. 
Peltier, A. et al., 2008. Cyclic magma storages and transfers at Piton de La Fournaise volcano (La Reunion hotspot) inferred from deformation and geochimical data. Earth and Planetary Science Letters 270 (3-4), 180-188.

Quidelleur, X., Hildenbrand, A., Samper, A., 2008. Causal link between Quaternary paleoclimatic changes and volcanic islands evolution. Geophysical Research Letters 35, L02303.

Quidelleur, X., Holt, J.W., Salvany, T., Bouquerel, H., 2010. New K-Ar ages from La Montagne massif, Reunion Island (Indian Ocean), supporting two geomagnetic events in the time period 2,2-2,0 Ma. Geophysical Journal International 182 (2), 699-710.

Rad, S.D., Allegre, C.J., Louvat, P., 2007. Hidden erosion on volcanic islands. Earth and Planetary Science Letters 262, 109-124.

Reimer, P.J. et al., 2009. Intcal09 and Marine09 radiocarbon age calibration curves, 0-50,000 years cal BP. Radiocarbon 51 (4), 1111-1150.

Rodriguez-Gonzales, A. et al., 2009. The Holocene volcanic history of Gran Canaria island: implications for volcanic hazards. Journal of Quaternary Science 24 (7), 697-709.

Rohling, E.J. et al., 2009. Antarctic temperature and global sea level closely coupled over the past five glacial cycles. Nature Geoscience 2, 500-504.

Saint-Ange, F. et al., 2011. A volcaniclastic deep-sea fan off La Réunion Island (Indian Ocean): gradualism versus catastrophism. Geology 39, 271-274.

Salvany, T., Lahitte, P., Nativel, P., Gillot, P.-Y., 2012. Geomorphic evolution of the Piton des Neiges volcano (Réunion Island, Indian Ocean): Competition between volcanic construction and erosion since 1.4 Ma. Geomorphology, doi:10.1016/j.geomorph.2011.06.009.

Schefuß, E., Kuhlmann, H., Mollenhauer, G., Prange, M., Pätzold, J., 2011. Forcing of wet phases in southeast Africa over the past 17, 000 years. Nature 480, 509-512. 
745 Schlager, W., Reijmer, J.J.G., Droxler, A.W., 1994. Highstand shedding of carbonate platforms. Journal of sedimentary Research B64 (3), 270-281.

747 Schmincke, H.U., Sumita, M., 1998. Volcanic evolution of Gran Canria reconstructed from

Schneider, J.L., Brunner, C.A., Kuttner, S., 1998. Epiclastic sedimentation during the upper Miocene-lower Pliocene volcanic hiatus of Gran Canaria: evidence from sites 953 and

Société Grenobloise d'Etudes et d'Application Hydrauliques (SOGREAH), 1998. Etude des risques hydrauliques sur la Rivière Saint-Etienne. report 554509 R1. 24 pp.

Stieltjes, L., Moutou, P., 1988. A statistical and probabilitic study of the historic activity of Piton de la Fournaise, Reunion Island, Indian Ocean. Journal of volcanology and geothermal Research 36, 67-86.

Thompson, P.R., Be, A.W.H., Duplessy, J.-C., Shackleton, N.J., 1979. Disappearance of pinkpigmented Globigerinoides ruber at $120,000 \mathrm{yr}$ BP in the Indian and Pacific Oceans. Nature 280 (5723), 554-558. 
769 Toucanne, S. et al., 2008. Activity of the turbidite levees of the Celtic-Armorican margin (Bay of Biscay) during the last 30,000 years: Imprints of the last European deglaciation and Heinrich events. Marine Geology 247, 84-103.

772 Toucanne, S., Zaragosi, S., Bourillet J.F., Dennielou, B., Jorry, S.J., Jouet, G., Cremer, M., 773 2012. External controls on turbidite sedimentation on the glacially-influenced Armorican margin (Bay of Biscay, western European margin). Marine Geology 303, 137-153.

776 Upton, B.G.J., Wadsworth, W.J., 1965. The basalt of Réunion Island, Indian Ocean. Bulletin 777 of volcanology $29,7-23$.

778

779 


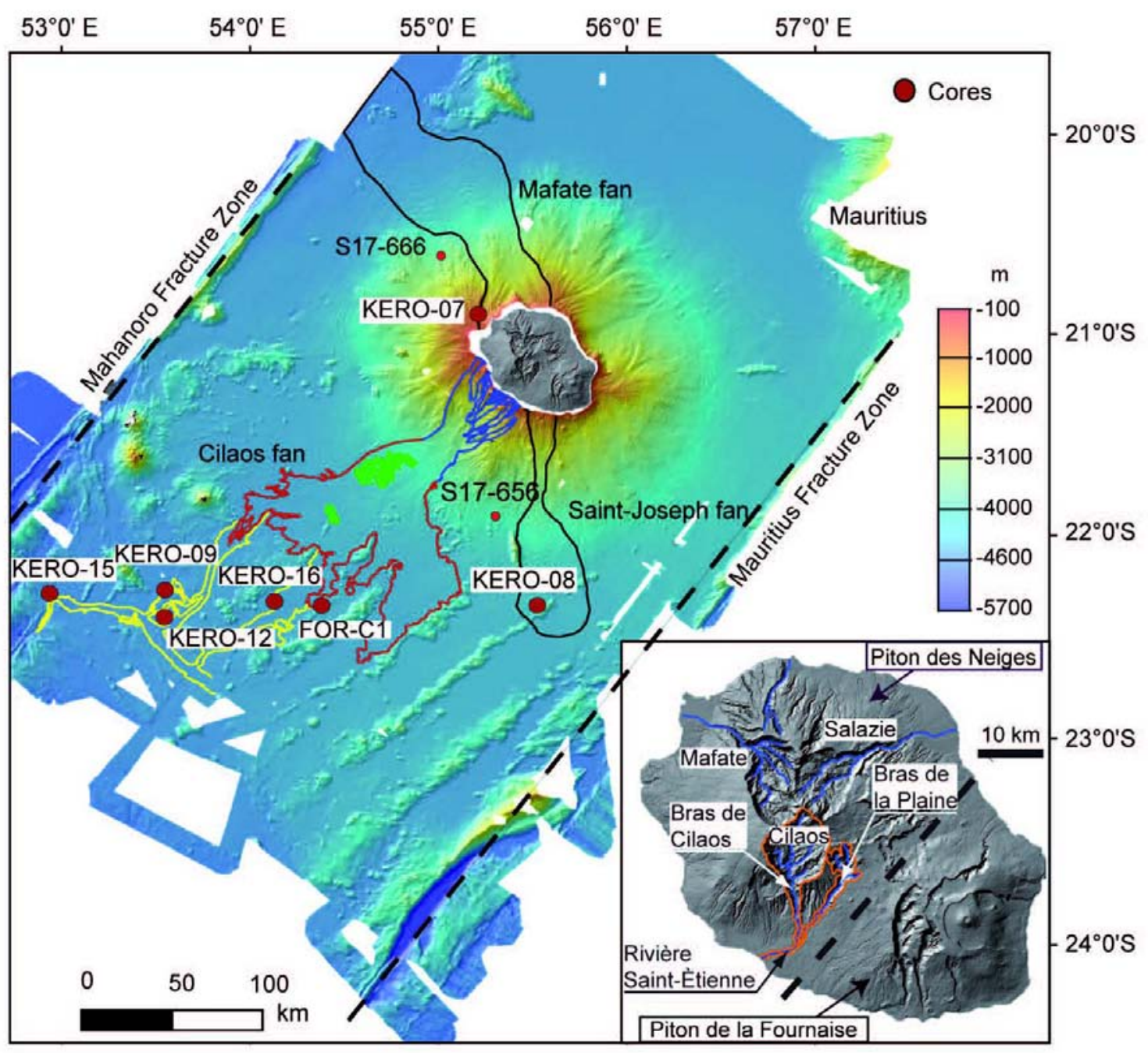

781

782

783

784

785

786

787

Fig. 1: Interpreted swath bathymetry image of the abyssal plain around La Réunion Island, compiled from the ERODER and FOREVER surveys. Red filled dots correspond to sediment cores presented in this paper. For the Cilaos fan, canyons are outlined in blue; the proximal fan in red and the distal part in yellow. Overview of the main geological structures of La Réunion Island (insert). The dashed line represents the separation between the two main volcanic edifices. The blue lines correspond to the main rivers draining the cirques. The orange lines delimit the main rivers feeding the Saint-Etienne river. 

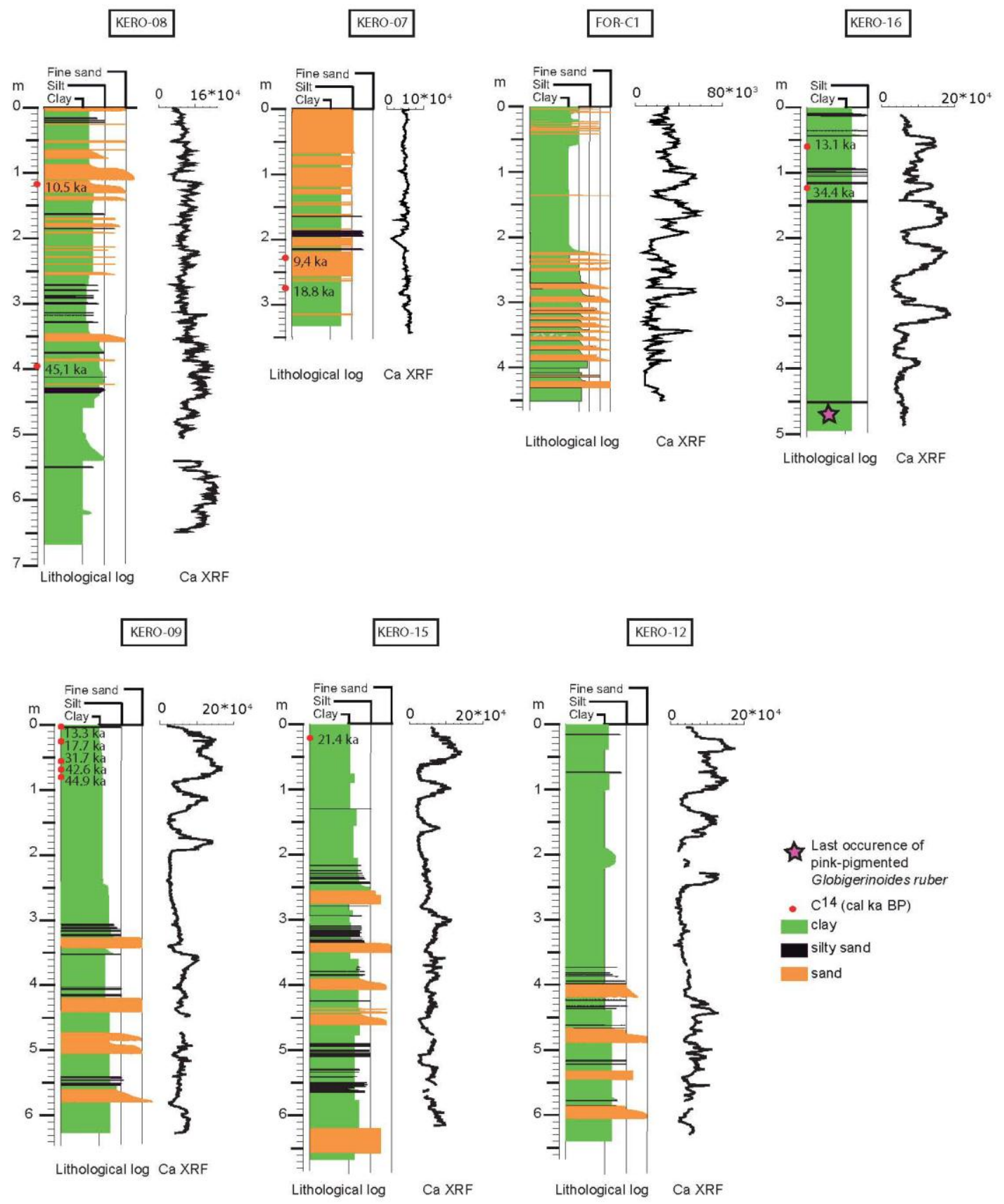

791 Fig. 2: Lithological logs, fluctuations of Calcium XRF, and AMS ${ }^{14} \mathrm{C}$ dates (cal ka BP) of 792 cores KERO-07, KERO-08, KERO-09, KERO-12, KERO-15, KERO-16 and FOR-C 1. 

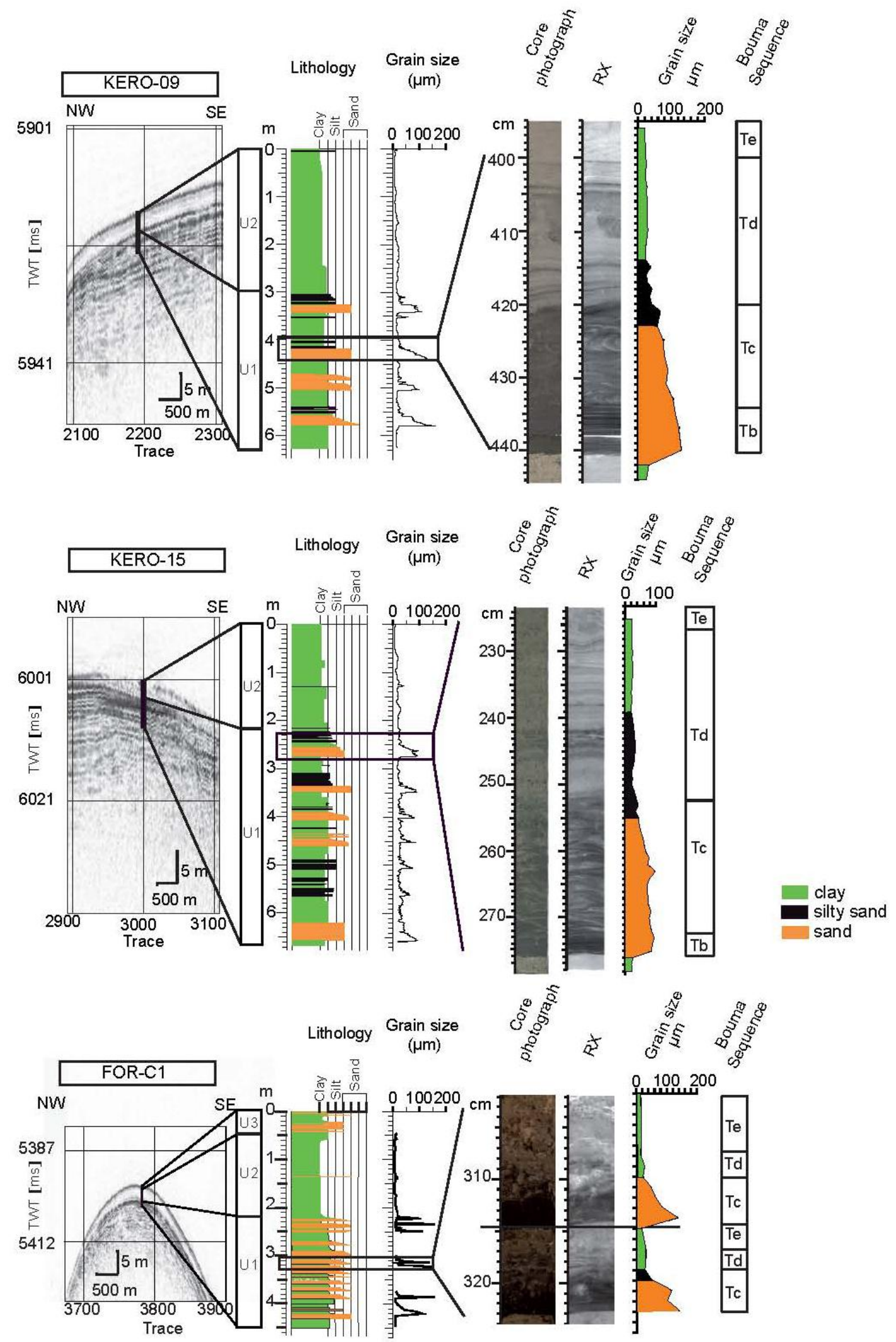

795 Fig. 3: Lithological log correlated with the corresponding echosounder profile, grain size curve and X-ray image of cores KERO-09, KERO-15 and FOR-C . 


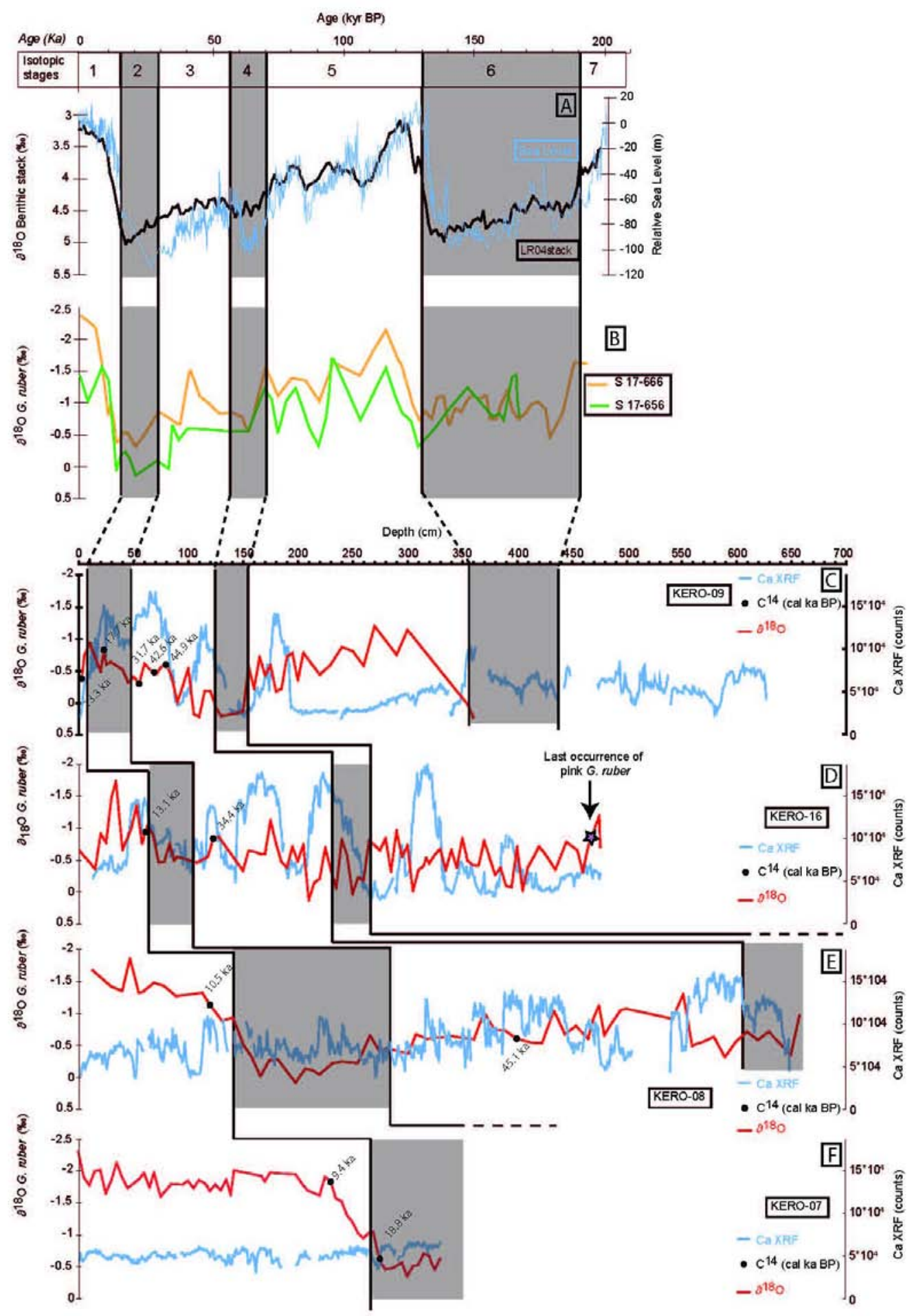

798 Fig. 4: A: LR04 $\delta^{18} \mathrm{O}$ benthic stack from Lisiecki and Raymo (2005). B: G. ruber $\delta^{18} \mathrm{O}$ of 799 cores S17-666 and S17-656 (Fretzdorff et al., 2000), locations shown on figure 1. C: G. ruber $800 \delta^{18} \mathrm{O}$ and Ca XRF of core KERO-09. D: G. $r u b e r \delta^{18} \mathrm{O}$ and Ca XRF of core KERO-16. E: $G$. 801 ruber $\delta^{18} \mathrm{O}$ and Ca XRF of core KERO-08. F: G. ruber $\delta^{18} \mathrm{O}$ and Ca XRF of core KERO-07. 


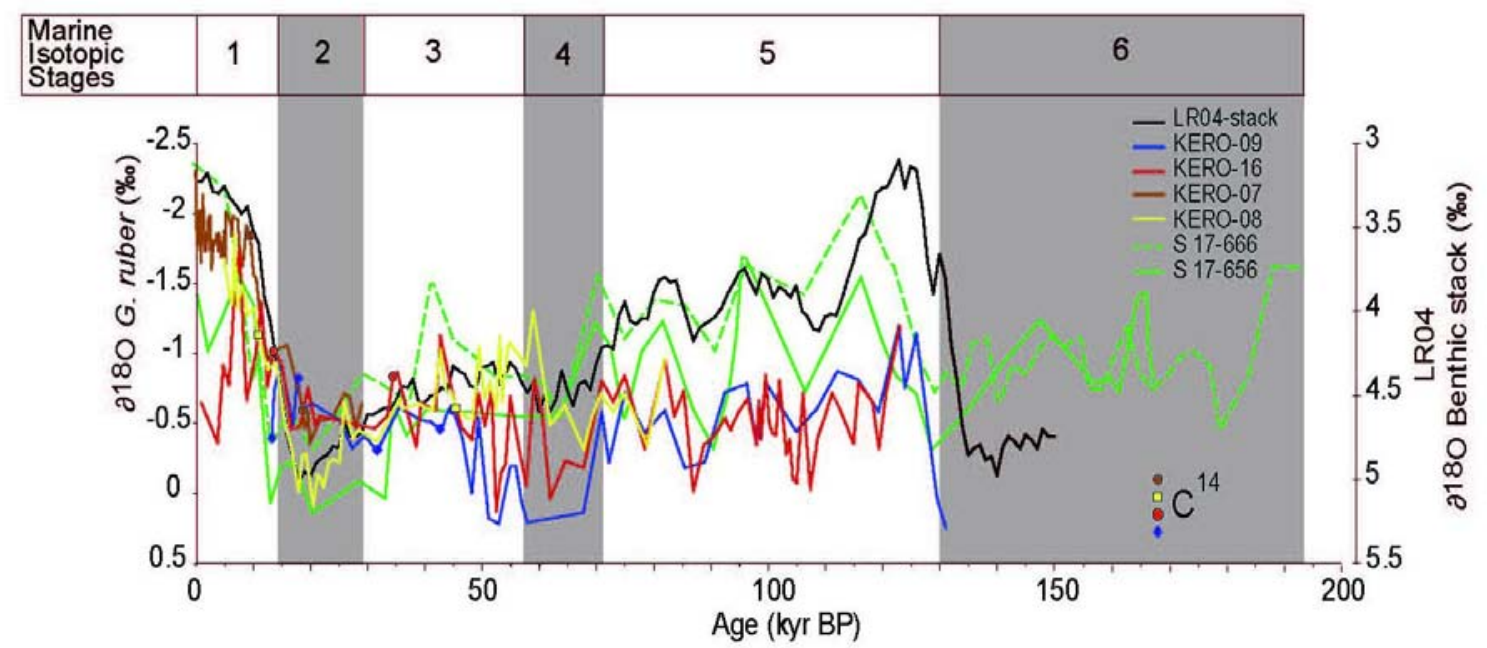

802

803 Fig. 5: $\delta^{18} \mathrm{O}$ curves of cores KERO-07, KERO-08, KERO-09 and KERO-16 compared with 804 the LR04-stack curve of Lisiecki and Raymo (2005).

805

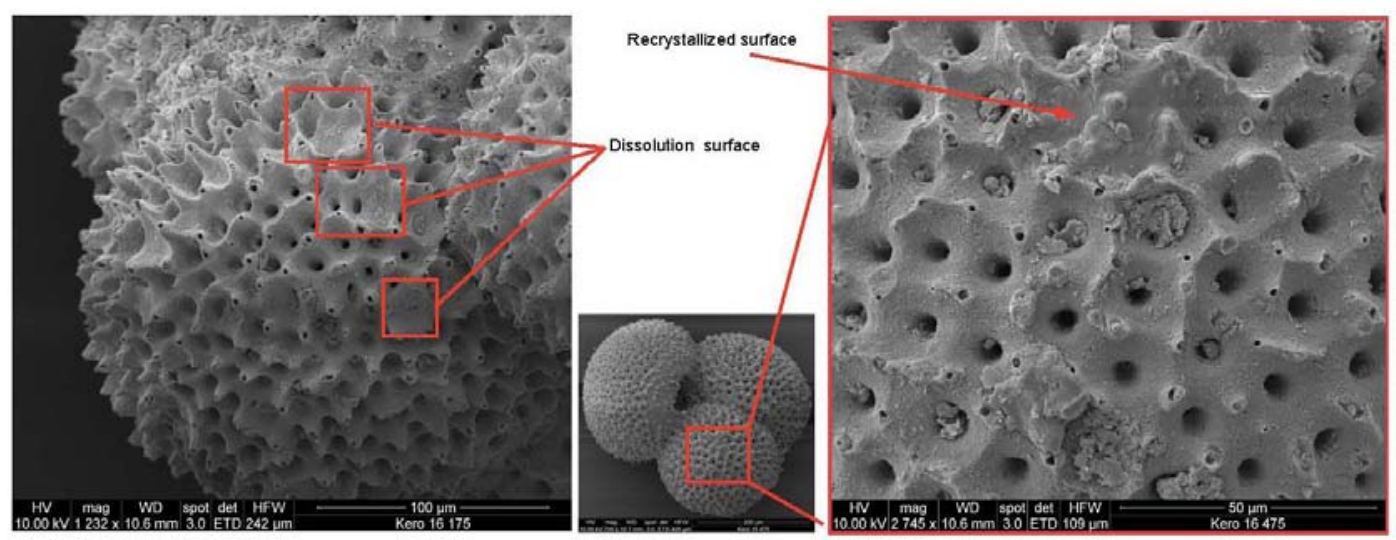

806 Fig. 6: SEM microphotographs of G. ruber from core KERO-16. Recrystallization and 807 dissolution surfaces are indicated on test surfaces.

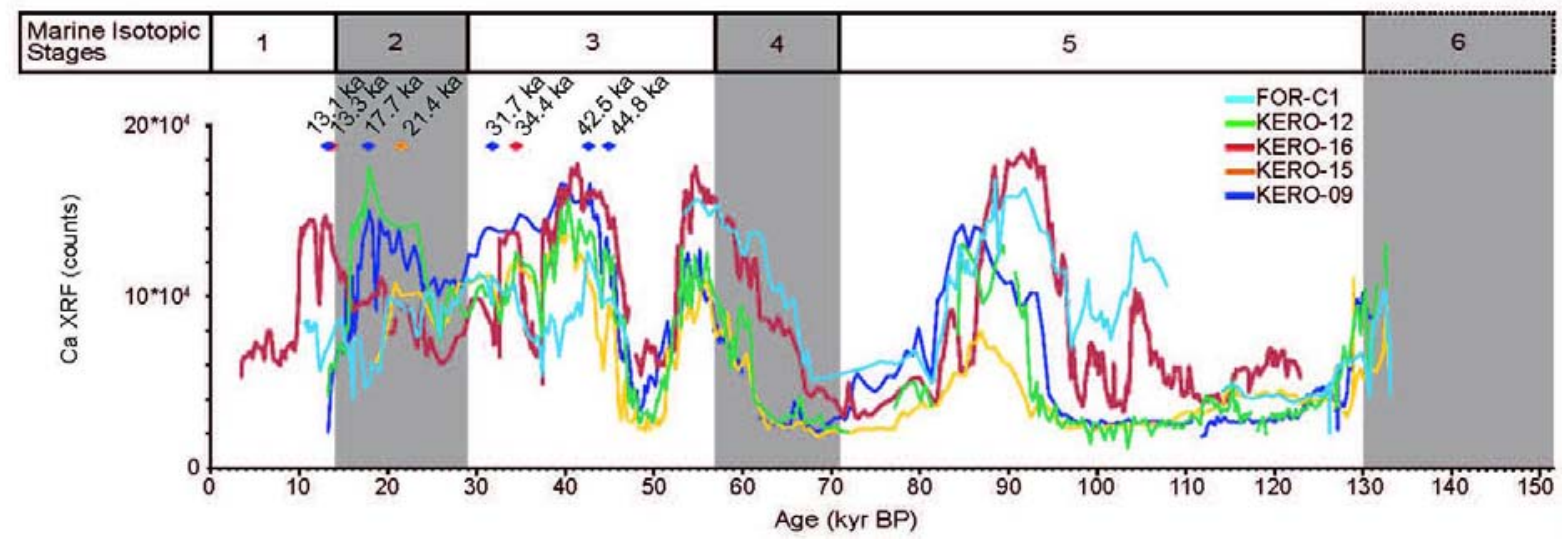

809 Fig. 7: Fluctuations of Calcium XRF for all the studied cores in the Cilaos deep-sea fan. 


\begin{tabular}{|c|c|c|c|c|cc|c|}
\hline $\begin{array}{c}\text { Marine Isotopic } \\
\text { Stages }\end{array}$ & 1 & 2 & 3 & 4 & 5 & 6 \\
\hline Age (kyr BP) & 0 & 20 & 40 & 60 & 80 & 100 & 120 \\
\hline
\end{tabular}
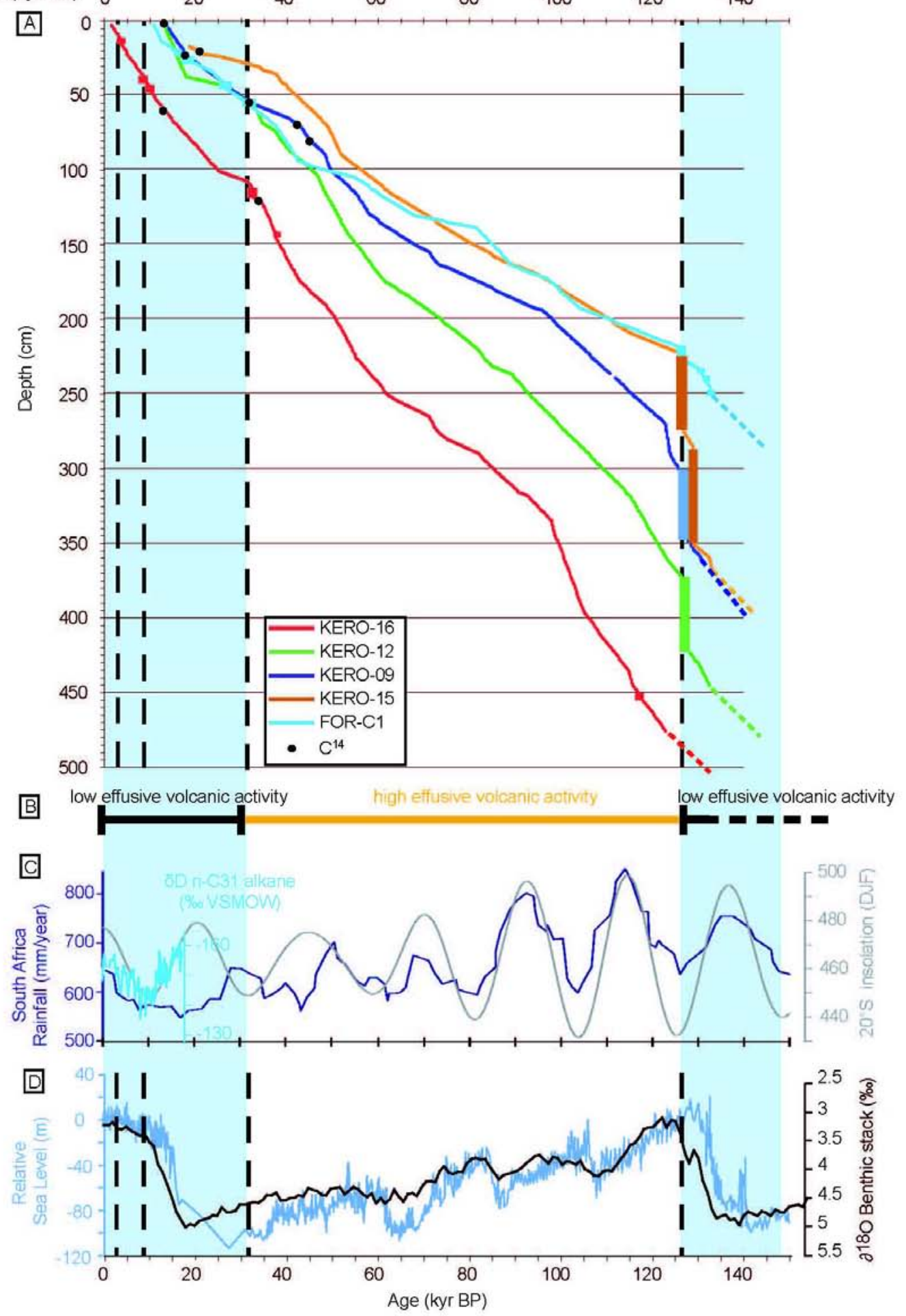

811 Fig. 8: Timing of turbidite deposition in the Cilaos deep-sea fan. Blue areas indicate periods

812 of major turbidite activity. The black dotted lines show the location of main turbidites. A)

813 Age/depth model of the five cores KERO-09, KERO-12, KERO-15, KERO-16 and FOR-C1, 
814 showing the location of turbidite beds in each core (turbidite beds are represented by

815 rectangles along each age/depth curves; their vertical size is proportional to the turbidite

816 thickness along the depth axis). Black dots show AMS ${ }^{14} \mathrm{C}$ dates. B) Major volcanic episodes

817 of Piton des Neiges during the Late Quaternary. Dataset from Kluska (1997), Salvany et al.

818 (2012). C) Hydrogen isotope compositions of the n-C31 alkane in GeoB9307-3, reflecting

819 rainfall changes in the Zambezi catchment (Schefuß et al., 2012), Pretoria rainfall time series

820 from Patridge et al. (1997) and insolation curve from Berger (1978). D) Red Sea sea level

821 curve from core GeoTü-KL09 (Rohling et al., 2009) and LR04-stack curve of Lisiecki and

822 Raymo (2005).

823

824

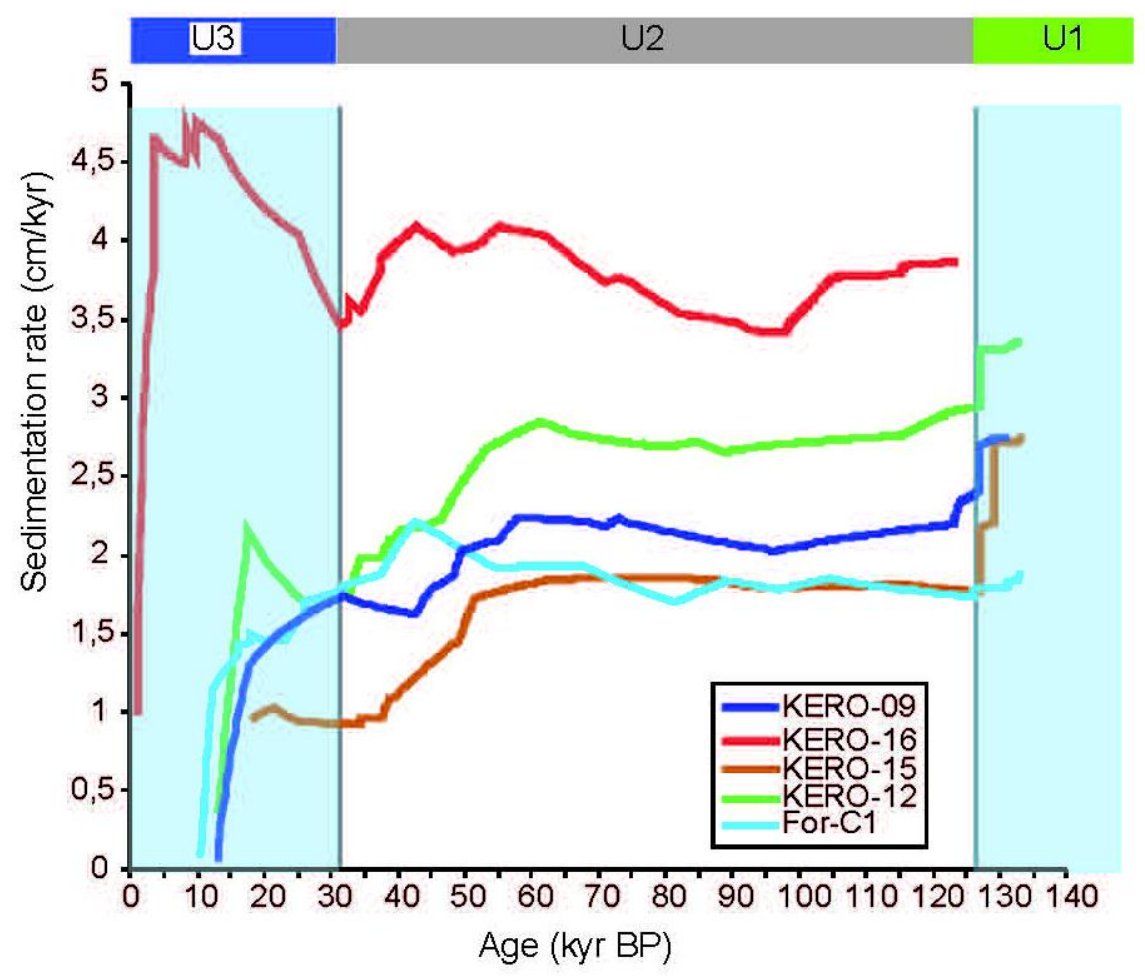

825 Fig. 9: Sedimentation rate of the five cores of the Cilaos fan plotted versus time. 
Since 30 ka: Erosion and turbidite activity (U3 deposition)
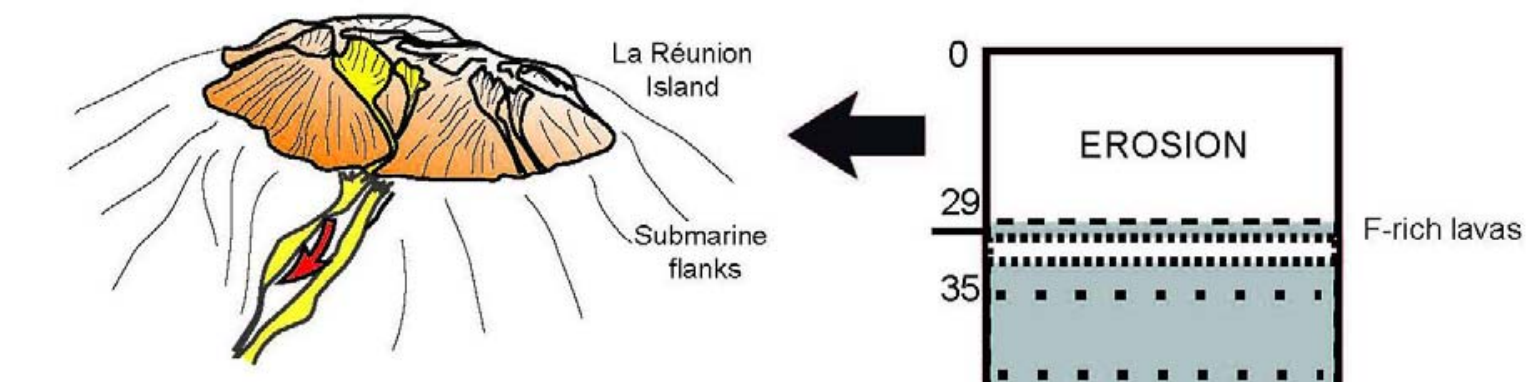

127-30 ka: Effusive volcanic activity filling the cirque and fluvial valleys

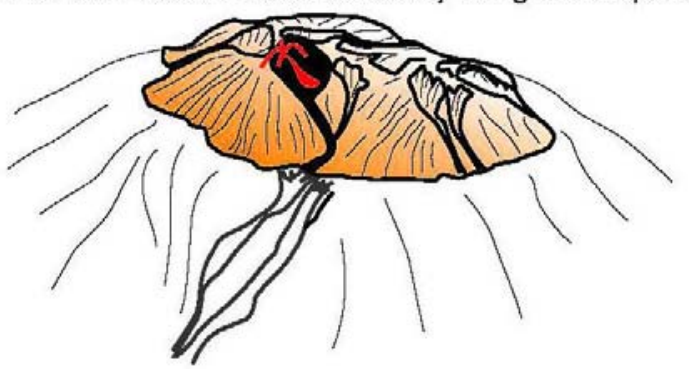

Before 127 ka: Erosion and turbidite activity (U1 deposition)
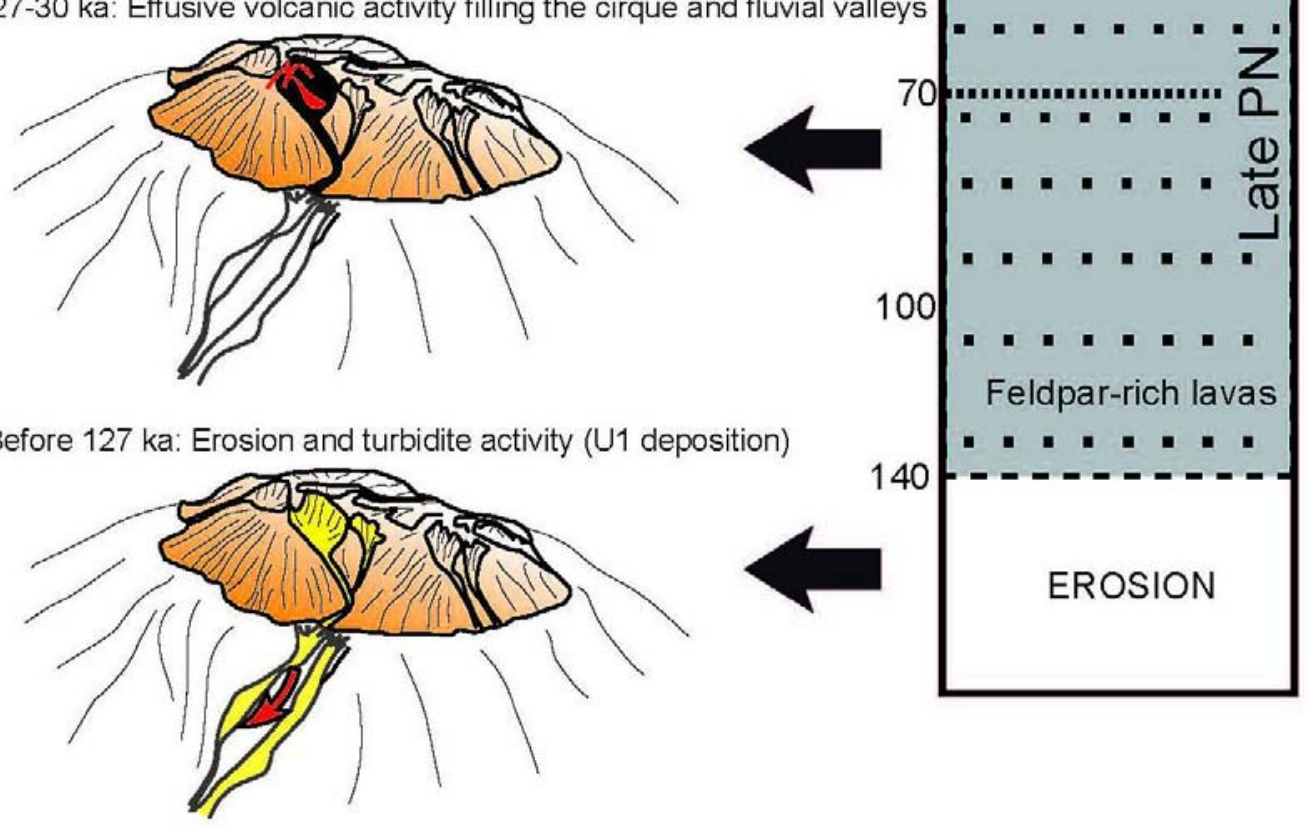

827 Fig. 10: Schematic representation of the transport of sediments on the Cilaos deep-sea fan and

828 volcano-stratigraphic units of Piton des Neiges (modified from Salvany et al., 2012). 


\begin{tabular}{|c|c|c|c|c|c|c|}
\hline Cruises & Cores & Lat $(\mathrm{S})$ & Long (E) & $\begin{array}{l}\text { Water } \\
\text { Depth } \\
\text { (m) }\end{array}$ & Location & $\begin{array}{l}\text { Length } \\
\text { (m) }\end{array}$ \\
\hline FOREVER & FOR-C1 & $\mathrm{S} 22^{\circ} 20.95$ & $\mathrm{E} 54^{\circ} 23.33$ & 4074 & $\begin{array}{l}\text { Sedimentary ridge, } \\
\text { Central Cilaos Fan }\end{array}$ & 4.51 \\
\hline ERODER1 & KERO-07 & S2053.59 & $\mathrm{E} 55^{\circ} 12.19$ & 791 & Levee, Mafate fan & 3.40 \\
\hline ERODER 2 & KERO-08 & $\mathrm{S} 22^{\circ} 20.89$ & E $55^{\circ} 31.12$ & 4126 & $\begin{array}{l}\text { Distal part of Saint- } \\
\text { Joseph fan }\end{array}$ & 6.59 \\
\hline ERODER 2 & KERO-09 & $\mathrm{S} 22^{\circ} 16.347$ & $\mathrm{E} 53^{\circ} 33.060$ & 4460 & $\begin{array}{l}\text { Levee, Occ. Cilaos } \\
\text { Fan }\end{array}$ & 6.27 \\
\hline ERODER 2 & KERO-12 & $\mathrm{S} 22^{\circ} 23.550$ & $\mathrm{E}^{\circ} 3^{\circ} 32.752$ & 4461 & $\begin{array}{l}\text { Levee, Occ. Cilaos } \\
\text { Fan }\end{array}$ & 6.40 \\
\hline ERODER 2 & KERO-15 & $\mathrm{S} 22^{\circ} 17.39$ & $\mathrm{E} 52^{\circ} 56.10$ & 4529 & $\begin{array}{l}\text { Distal levee, Occ. } \\
\text { Cilaos Fan }\end{array}$ & 6.68 \\
\hline ERODER 2 & KERO-16 & $\mathrm{S} 22^{\circ} 19.51$ & $\mathrm{E} 54^{\circ} 07.78$ & 4340 & $\begin{array}{ll}\text { Levee, } & \text { Central } \\
\text { Cilaos Fan } & \end{array}$ & 4.95 \\
\hline
\end{tabular}

831

832 Table 1 : Location, bathymetry and length of the studied cores 
834

\begin{tabular}{|c|c|c|c|c|c|c|}
\hline \multirow[t]{2}{*}{$\begin{array}{l}\text { Laboratory } \\
\text { number }\end{array}$} & \multirow[t]{2}{*}{ Core } & Depth & \multirow[t]{2}{*}{$\begin{array}{c}\text { AMS 14C } \\
\text { age (yr) }\end{array}$} & \multirow{2}{*}{$\begin{array}{c}\text { AMS 14C } \\
\text { age } \\
(-400 \mathrm{yr})\end{array}$} & \multirow[t]{2}{*}{ Error yr } & \multirow{2}{*}{$\frac{\text { Calendar Age }}{\text { (cal yr BP) }}$} \\
\hline & & $(\mathrm{cm} \mathrm{bsf})$ & & & & \\
\hline Poz-35177 & KERO-09 & 3 & 11840 & 11440 & 60 & 13302 \\
\hline Poz-35178 & KERO-09 & 23 & 14980 & 14580 & 70 & 17739 \\
\hline Poz-35179 & KERO-09 & 55 & 28000 & 27600 & 240 & 31723 \\
\hline Poz-35180 & KERO-09 & 69 & 38500 & 38100 & 600 & 42587 \\
\hline Poz-35181 & KERO-09 & 80 & 41700 & 41300 & 1000 & 44883 \\
\hline SacA 24240 & KERO-08 & $118-119$ & 9680 & 9280 & 40 & 10543 \\
\hline SacA 24241 & KERO-08 & $395-396$ & 42060 & 41660 & 690 & 45133 \\
\hline SacA 24239 & KERO-07 & $229-230$ & 8755 & 8355 & 40 & 9436 \\
\hline SacA 21880 & KERO-07 & 274.5 & 16110 & 15710 & 50 & 18834 \\
\hline SacA 21881 & KERO-15 & 21.5 & 18390 & 17990 & 60 & 21443 \\
\hline SacA 21882 & KERO-16 & 60.5 & 11610 & 11210 & 35 & 13118 \\
\hline SacA 21883 & KERO-16 & 122.5 & 29660 & 29260 & 160 & 34422 \\
\hline
\end{tabular}

835

836

837

Table 2 : Radiocarbon dates from cores KERO-07, KERO-08, KERO-09, KERO-15 and 838 KERO-16

839 


\begin{tabular}{|c|c|l|l|}
\hline Sample & $\begin{array}{c}\text { Depth } \\
\text { (cm bsf })\end{array}$ & Sedimentary Facies & Observation \\
\hline KERO-09-65 & 65 & $\begin{array}{l}\text { Layer of light brown clay, } \\
\text { located in the upper part of } \\
\text { the core }\end{array}$ & $\begin{array}{l}\text { Emiliania huxleyi abundant } \\
(<75-90 \text { Ka) }\end{array}$ \\
\hline KERO-09-115 & 115 & Layer of light brown clay, & $\begin{array}{l}\text { Abundant, good preservation, } \\
\text { Pseudoemiliania lacunosa } \\
\text { being absent (<460 ka) and } \\
\text { contains Emiliania huxleyi } \\
(<260 \text { ka) }\end{array}$ \\
\hline KERO-09-117 & 117 & Layer of light brown clay & $\begin{array}{l}\text { Abundant, good preservation, } \\
\text { Pseudoemiliania lacunosa } \\
\text { being absent (<460 ka) and } \\
\text { contains Emiliania huxleyi } \\
(<260 \text { ka) }\end{array}$ \\
\hline KERO-09-361 & 361 & $\begin{array}{l}\text { Layer of brown clay, } \\
\text { located between two sndy } \\
\text { layers }\end{array}$ & $\begin{array}{l}\text { Abundant, good preservation, } \\
\text { Pseudoemiliania lacunosa } \\
\text { being absent (<460 ka) and } \\
\text { contains Emiliania huxleyi } \\
(<260 \text { ka). Reworked } \\
\text { nannofossils } \\
\text { were noted }\end{array}$ \\
\hline KERO-09-608 & 608 & $\begin{array}{l}\text { Layer of brown clay, } \\
\text { located in the lower part of } \\
\text { the core }\end{array}$ & $\begin{array}{l}\text { Abundant, poor preservation. } \\
\text { Gephyrocapsa spp cf } \\
\text { caribbeanica dominant. Two } \\
\text { specimens of Pseudoemiliania } \\
\text { lacunosa } \text { suggest age }<460 \mathrm{ka} .\end{array}$ \\
\hline
\end{tabular}

841

842

843

844

845

Table 3 : Calcareous nannofossil data of core KERO-09. Age from Berggren et al. (1995). 